\title{
The Determination of Specific Characters for the Identification of Certain Ascidians.
}

\author{
By \\ Sheila Taylor Lindsay, B.Sc., \\ and \\ Harold Thompson, M.A., D.Sc , \\ Fishery Board for Scotland, Aberdeen.
}

With Plates 1-8 and 1 Figure in the-Text.

\section{CONTENTS.}

INTRODUCTION .

1. Comparative Study of the Forms recently included in Gen. Ascidiella . 3

2. Variation in other Species of Fam. Ascidiidce . . . . . . 20

3. A suggested Key to the Boreal Species of Fam. Ascidida. $\quad$. $\quad 29$

4. SyNONYMY .

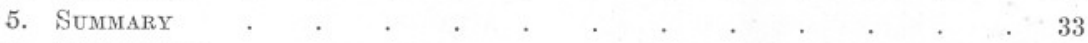

6. References . . . . . . . . . . . . . . . . . . . . . . . . 34

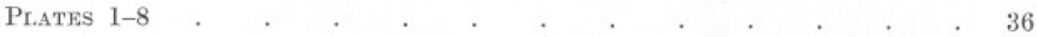

\section{INTRODUCTION.}

In the course of a study involving the routine identification of Tunicata the need became apparent of an attempt being made to define more clearly than has been done the diagnostic characters of certain species. The examination of a widely-collected material demonstrates the fact that in certain species considerable variations in structure accompany changes of habitat (depth, latitude, temperature, type of substratum, etc.), while other species vary but slightly. Thus if reference be made to the most recent comprehensive work on British Tunicates (2) it is found that in some cases many species - all mere varieties of one definite species (e.g. Ascidia mentula) - have been described, while in others (e.g. Ascidia obliqua) the features of but one form are given, there being no confusion due to apparent modifications of that form. Hartmeyer (6) revised Alder and Hancock's list of species, uniting many closely related forms under specific names not always adhered to in his later work ( $\boldsymbol{( y})$. In many cases his conclusions were inevitable and have been accepted by more recent workers on the phylum. In connection with certain other cases, however, a distinct tendency has developed to consider that he has subordinated under one name two or more forms sufficiently clearly demarcated to warrant some kind of separate recognition. Thus Ârnbâch 
(15) and Berrill (3) have inter alia devoted more special attention to the Family Molgulida, without, however, leaving the systematic position quite clear. It is a particular merit of the latter author's work that he redirects attention to the importance of developmental characters, concerning which a vast amount of accurate information seems yet to be lacking. At the same time, on practical grounds it is requisite that ontogenetic peculiarities should be correlated with recognisable differences of adult structure, since specific diagnosis must perforce most often be made upon preserved material. Definition of the range of variation of both developmental and adult characters is the desideratum.

Within the limits of the available facilities this paper deals with the type Family Ascidiidae of the phylum, and gives the results of a semistatistical study of material collected over a wide area (with northern and southern limits of Iceland and the English Channel respectively) wherein the nature of the habitat is sufficiently diversified to give rise to at least a fair amount of structural variation.

With two exceptions the species dealt with here were at various times kept in the live state either on board a research vessel or in the laboratory, ${ }^{*}$ the object being to obtain for study the eggs, larvæ, and early fixed stages. This object was imperfectly attained. Thus species such as A. mentula, virginea, conchilega, and mammillata, which are not indigenous in the sea near the laboratory, and which had to be transported thither from a distance, gave rather meagre results. Even on the west Scottish coast, where they are common, and where they were kept on board ship, $A$. mentula and $A$. conchilega did not readily shed the reproductive elements. By contrast $A$. aspersa and $A$. scabra-particularly the latter-displayed enormous reproductive activity whether kept aboard ship or in the laboratory, in the neighbouring waters of which only the latter of these species is indigenous. The shedding of eggs could, in the case of $A$. scabra, usually be induced if necessary by the slight raising of the temperature of the water, but in no case did the other species respond to this stimulus. It is perhaps owing to its great fecundity that A. scabra is by far the commonest British Ascidian.

Two or more individuals of each species were kept in large aerated jars. No food was given except that contained naturally in the frequent changes of sea-water supplied. Under these conditions the smaller animals appeared to live quite healthily for months, but large individuals of $A$. mentula, mammillata, and aspersa could not be kept in condition for more than two or three weeks. No attempt at artificial fertilisation of eggs was made. The latter could be seen being intermittently expelled. In the case of any one individual the shedding of eggs in groups would proceed thus for 24-36 hours during spells of activity occurring every few weeks.

* Scottish Fishery Board, Aberdeen. 
Development of the eggs as far as the larval stage was always easily obtained, but under the conditions the metamorphosing larva almost always died before reaching the fixed stage. Only in the case of $A$. scabra 'was the fixed stage showing protostigmata obtained. The specific evidence submitted below therefore relates mainly to the production of certain forms of eggs and larvæ by species whose body characters are defined.

Roule (20) suggested the establishment of 3 genera within what is now recognised as Fam. Ascidiida, and these have been accepted (with some reservation) by other authors, partly, we think, since the establishment of the genus Ascidiella segregated a set of troublesome and confusing forms, leaving the genera Ascidia and Phallusia to be devoted to easily distinguishable species. It is to the study of the constancy and the relative specific value of the developmental and anatomical characters of the confusing forms more recently recognised under Genus Ascidiella that this paper is chiefly devoted. Collateral work has, however, been done on a scantier material relating to the other species of the Family. For reasons to be given below we incline to the opinion that, in the light of the facts presented here, the retention of the Ascidiella forms in a separate genus is not warranted.

\section{Comparative Study of the Forms recently included in Genus Ascidiella (Roule, 1883, modified).}

As treated by Hartmeyer ( $(y)$ Gen. Ascidiella contains only one species -A. aspersa (Müll. 1776). It was that author's considered opinion that the three forms recognised by Herdman (12) are mere varieties of this species. The latter author did indeed call attention, as did Roule, to the existence of transitional forms apparently linking up one with another of his types. The first and largest type was named Ascidiella aspersa; the two others- $A$. virginea and $A$. scabra-were much smaller and could be inter-distinguished by their habit, the former being erect, the latter recumbent and attached by the greater length of its side.

Roule's definition of Gen. Ascidiella brought in three Ascidian species (A. virginea, obliqua, prunum) which have since been excluded by the alteration of that definition to the following :-

a. Nerve ganglion almost directly above the dorsal tubercle.

$b$. The branchial papillæ are reduced.

It is chiefly on the constancy of character $b$ that Gen. Ascidiella is based. All that is, however, implied by the term reduction is that free papillæ, as found in other species (Plate 7, Fig. 3), do not occur, although in certain portions of the branchial sac-e.g. near the mouth-a rudimentary state may persist (Plate 7, Fig. 2). In the latter case irregular 
bosses arise from the transverse vessels and either remain isolated or become more or less linked up with each other by the outgrowth of longitudinal spurs. In cases where these bosses are numerous they might be mistaken for papillæ. Normally, however, they are completely linked up by longitudinal vessels (Plate 7, Fig. 1) and are seen only as thickened portions of these bars. Instead of growing out into true free papillæ they have the appearance of being repressed back on to the transverse vessels by means of their association with a transverse papillary membrane which links them together laterally. The experienced worker has no difficulty in recognising Gen. Ascidiella from this peculiarity of sac structure.

The point to be investigated here is the number of species capable of clear distinction within this genus. Can the reduction from Herdman's three forms to Hartmeyer's one be justified ? The latter author certainly has not submitted a thorough analysis of the forms. Berrill claims that at least two, and possibly three, species are to be distinguished. We may recapitulate the points in which he finds form aspersa to differ from form scabra.

A. aspersa.-Attached basally ; attains maximum size of $12-13 \mathrm{~cm}$. ; any mantle pigment present is localised near the siphons; has the renal bodies extensively distributed over the mantle; has floating egg, with very large outer follicle cells.

A. scabra.-Attached by side ; size restricted to $4 \mathrm{~cm}$. ; has red pigment spread usually over most of the mantle and has the atrial siphon relatively nearer the branchial than is the case in $A$. aspersa; the renal bodies are less extensively distributed; the egg is non-floating, with small outer follicle cells and the chorion raised further from the ovum surface than is the case in the egg of aspersa.

The third possible form (Herdman's A. virginea) is said to differ from form scabra, which it most resembles, in possessing a deep, diffusely spread brown pigment, and in forming eggs in which the perivitelline space is narrower.

At the outset of this study an attempt was made to keep forms resembling scabra and virginea separate, but no justification could be found for so doing. Their eggs and larvæ appear to be identical respectively, and in outward appearance the two extremes of form are linked up by a range of intermediate forms. In addition there is no consistent anatomical difference between them, although in certain habitats the erect, in others the recumbent form may be that more commonly found. The characters of the two forms and their intermediaries are therefore combined here and are submitted under the name scabra, thus being contrasted with those of form aspersa.

We have had the opportunity of examining the material from over 
200 collections of form scabra and from 11 collections of form aspersa, which is obviously a comparatively rare species in British waters. While dissections were made only on the following specimens selected from this wider material, it is to be emphasised that rougher examination of the remainder served to confirm the conclusions arrived at.

A. aspersa. - 22 specimens, length 7-76 mm., taken from shallow water, Plymouth; 11 spec., 30-72 mm., 41 metres, Loch Fyne ; 2 spec., 37-50 mm., 40 metres, Loch Duich; 1 spec., 18 mm., 10 metres, Lochmaddy (North Uist) ; 1 spec., $42 \mathrm{~mm}$., between tide-marks, Olna Firth, Shetland ; 25 spec., 8-31 mm., 7-12 metres, Loch Indail, Islay ; 2 spec., 37-56 mm., 7-17 metres, Ettrick Bay.

A. scabra.-13 spec., 8-29 mm., Eddystone Grounds ; 11 spec., 28-35 mm., 11-20 metres, Luce Bay ; 30 spec., 12-43 mm., 48 metres, Firth of Clyde; 7 spec., 27-35 mm., 41-138 metres, Loch Fyne; 5 spec., 20-29 mm., 16-28 metres, Islay; 15 spec., 22-36 mm., 80 metres, between Skye and Mull; 30 spec., 15-38 mm., 103 metres, Hoy, Orkney; 30 spec., 6-34 mm., 123 metres, Scalloway, Shetland; 38 spec., 16-31 mm., 142 metres, E. of Balta, Shetland; 15 spec., 15-37 mm., 107 metres, Northern North Sea ; 43 spec., 6-47 mm., 62 metres, Northern Moray Firth; 10 spec., 15-41 mm., 82 metres, 50 miles E.S.E. of Aberdeen; 18 spec., 9-39 mm., 15 metres, Kirkcaldy Bay; 30 spec., 24-73 mm., 36 metres, Dogger Bank (north edge); 30 spec., 19-53 mm., 42 metres, Dogger Bank (Tail End).

The following are the results of the investigations of the characteristic features of these two forms :-

(A) Geographical and Bathymetrical Distribution.-If two otherwise closely allied forms have precisely the same distribution the case for considering them the same species is strengthened. Owing to confusion. in nomenclature it is not always clear to which form authors have referred, but it can be said that $A$. aspersa is in general found in much shallower water than is A. scabra. The former is commonest in harbours, river estuaries, etc., and can succeed in brackish water; it is found coastally from the Mediterranean to the latitude of Shetland, but as far as is known it is absent from the east British coast (except from the Thames estuary). Although it occurs on the south Norwegian coast it is doubtful if it extends much distance northwards along the west coast. The records from Ettrick Bay, Islay, Loch Duich, and Olna Firth are new. North of the English Channel this species is rare. A. scabra, however, is taken in great numbers at all points where its congener occurs; it favours deeper water (5-300 metres as compared with 
0-50 metres), and is the commonest Ascidian of the North Sea, where $A$. aspersa is lacking. It also extends further north than that species, being found at Faroe and Trondhjem. There is therefore far from complete coincidence between the distribution of the two forms. At the same time they often occur in close association, and were they similar in almost all other respects might be considered as shallow- and deep-water forms of the same species.

(B) Size.-In the English Channel where it is fairly common A. aspersa can, according to Berrill, attain $13 \mathrm{~cm}$. in size. The average size is, however, probably no more than 6-7 $\mathrm{cm}$. Scottish specimens tend to be smaller even than this. Scabra rarely exceeds $2-3 \mathrm{~cm}$. in mean size, and 4-5 cm. in maximum size. On the Dogger Bank, however, a maximum size of $7 \frac{1}{2} \mathrm{~cm}$., if not more, is reached. Conversely the maximum size in areas in which the recumbent form predominates is seldom more than $3 \frac{1}{2} \mathrm{~cm}$. (All these measurements, with the exception of Berrill's, refer to the antero-posterior dimension, omitting the length of the siphons, which varies with the extent of their contraction.) Aspersa is therefore, on the average, at least twice as large as scabra.

(C) Attachment to Substratum.-There is by no means uniformity of degree of fixation in either aspersa or scabra (or, for that matter in most other species). Thus although $A$. aspersa has hitherto been regarded as a basally attached animal, we have obtained in Loch Indail, Islay, a group of specimens (Plate 5, Fig. 2) attached by nearly the whole side. These occurred in the shallow water of a bay exposed to the scouring action of south-westerly swells, and erect, slightly attached individuals would in such a position encounter severe buffeting. The fixation was to a large Cyprina valve which was firmly silted down into the sand. These animals were not dissected since it was desirable to retain them as type specimens, but they resembled $A$. aspersa in size, nature of test, position of apertures, and type of egg. The occurrence of adult individuals so fully attached is doubtless very exceptional. In the Plymouth material 23 individuals were fixed basally and one by half of its side. Twenty of the Loch Fyne animals were attached basally, and two by half the side. It is noteworthy that in the Plymouth material of Ascidia virginea, a species hitherto thought always to be erect, a parallel case was encountered (Plate 4, Fig. 6) where an individual was wholly attached by its side to the valve of a Scallop.

Turning now to $A$. scabra, we find that there is no justification for the establishment of two species (scabra and virginea) on the score that one is attached by the whole or the greater part of the side, the other basally. All Dogger Bank specimens were found to be basally fixed, either to a Lamellibranch valve (Plate 4, Fig. 4) or by means of a conical root-like prolongation of the test substance into the sand. All of the 
Firth of Clyde, Orkney, and Islay individuals were also attached by the bases. In the other areas (Plymouth excepted) practically all were so fixed, but a greater or less tendency was displayed for certain individuals to have more extensive attachment (Plate 4, Fig. 1). Only of the Plymouth material could it be said that the predominant tendency was towards complete attachment.

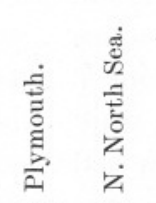

Basal . . . 3010

One-third of side : $\quad 2 \quad-$

Half of side . $\quad . \quad 7 \quad 1$.

$\begin{array}{llll}\text { Two-thirds of side } & 7 & 1\end{array}$

Three-fourths of side $\quad . \quad 3 \quad 2$

Whole side.

It is probable that the recumbent form tends most frequently to be found where stones, shell-valves, seaweed-fronds, etc., occur to afford the basis of attachment, and where, in addition, a large average size is not attained. Thus in the deep water of the northern North Sea, in very soft mud, it is natural to find more than normal use being made of hard objects for means of attachment. Any attempt, however, to establish constant points of anatomical difference as between flat and erect forms has been unsuccessful. On the other hand, as will be shown below, constant points of resemblance are capable of easy demonstration.

(D) Colour.-A. aspersa has been stated to differ from A. scabra in being practically colourless, whereas in adult individuals of the latter the mantle is usually more or less reddish-brown. This distinction can be said to hold in most cases, but it frequently breaks down. Our material has provided no pigmented forms of aspersa, but Alder and Hancock have illustrated their description of Ascidia Normani (=A. aspersa $)$ by means of a figure showing a brilliantly carminepigmented mantle, such as is often found in A. scabra. This does not agree with their description of the mantle as being of a pale buff fleshcolour or almost colourless. We conclude that the specimen figured is one of the exceptional pigmented forms, called by these authors A. Normani (var. resplendens).

On the other hand, almost or quite colourless forms of A. scabra are frequently found. For example, the large Dogger Bank individuals have at most the pale buff colour referred to above, while the beautifully transparent specimens from the inner Moray Firth (Plate 4, Fig. 3) are virtually free from pigment. Even the flat forms have their colourless variety (A. scabra var. albida of A. and $\mathrm{H}$.). 
The above distinction therefore applies only to the majority of cases and is not strictly specific.

(E) Nature of Test.-Here we deal with a character which falls just short of being absolutely specific. In $A$. aspersa, as the name signifies, the test of the young animals is more or less covered with fine papillæ. In cases where no pigment develops (e.g. in the west Highland sea lochs) the specimens present, at size $2-4 \mathrm{~cm}$., an attractive frosted appearance. In larger animals, however, the test becomes more or less coarsely pustulose (Plate 5, Fig. 1) and is cartilaginous in consistency, rather than gelatinous or coriaceous as in A. scabra, in which it is usually smooth or at most wrinkled, with occasionally a few papillæ round the siphons. The test in the neighbourhood of the siphons may indeed be strongly echinated (as in A. and H's A. scabra var. lavis), but it is possible that the var. echinata (Lamlash Bay, Arran) of these authors is a young stage of $A$. aspersa, since the papillæ extended over the test generally.

(F) Position of the Apertures.- - It has been held to be a distinguishing feature of $A$. aspersa that the atrial aperture is separated from the branchial by a distance equivalent to rather less than one-half of the body-length; whereas in A. scabra the distance is only one-quarter (and rather less than one-quarter in the recumbent forms). If we express the distance between the mid-points of the siphons as a fraction of the bodylength we find that out of 65 specimens of aspersa 32 gave one-third, 7 rather less than one-third, and 26 rather more than one-third. That is, the mean distance is in these cases rather greater than one-third, and the range of variation is from about one-fourth to just less than one-half.

In the case of $A$. scabra, out of 446 specimens 71 gave a ratio of onefifth, 311 of one-fourth, 58 of one-third, and 6 of one-half. The tendency towards the larger interval existed in areas in which the recumbent form was most numerous. The mean interval between the apertures was therefore about one-fourth of the body-length, and the variation on either side of that ratio was approximately balanced as between one-third and one-fifth.

Where it is desired to distinguish the species without dissection the distinction (between the mean ratios of one-third and one-fourth respectively) is of accessory value, but as has been shown some overlapping of the respective ratios occurs.

A note may be made here of the very rare occurrence of the persistence of an early post-larval character in A. scabra. From the Doghole, off Aberdeen, a specimen was taken with two atrial siphons (Plate 8). Herdman (10) records a similar case from Llandudno.

(G) Numbers of Branchial Stigmata per Mesh.-A mesh of the branchial sac may be defined as the rectangular area enclosed by the intersection of two adjacent longitudinal with two adjacent transverse vessels. Herdman 
(12) gave it as a distinction of $A$. aspersa that from 4-6 stigmata are formed in each mesh, as compared with from 7-12 in the recumbent form of $A$. scabra. Now were this the case there would be, in the number of stigmata, a specific point of difference between the two species.

The main features of a count of the stigmata in 29 specimens of $A$. aspersa and 316 specimens of $A$. scabra are shown in the following table, in which size 5 includes specimens ranging in size from $3-7 \mathrm{~mm}$, size 10 those ranging from $8-12 \mathrm{~mm}$., and so on. If it be remembered that $A$. aspersa is, age for age, much larger than $A$. scabra, it is probably the best interpretation of the results to deduce that, stage for stage, though not of course size for size, both forms have approximately the same number of stigmata per mesh, and that this number increases with age to a rather definite maximum average number (6-8). Now this maximum is attained by $A$. scabra at a smaller size than by $A$. aspersa (witness the attainment of the maximum range-4 to 9 - at size $20 \mathrm{~mm}$. in the case of the former, and, in that of the latter, the maximum of 6 to 8 at size $40 \mathrm{~mm}$.).

\begin{tabular}{|c|c|c|c|c|c|c|}
\hline \multirow{3}{*}{$\begin{array}{c}\text { Size } \\
(\mathrm{mm} .) .\end{array}$} & \multicolumn{6}{|c|}{ No. of Stigmata per Mesh. } \\
\hline & & aspersa. & & & A. scabra. & \\
\hline & $\begin{array}{l}\text { No. of } \\
\text { Specimens. }\end{array}$ & Range. & Mean. & Mean. & $\begin{array}{l}\text { Mean } \\
\text { Range. }\end{array}$ & $\begin{array}{c}\text { No. of } \\
\text { Specimens. }\end{array}$ \\
\hline 5 & - & - & - & 3.3 & $3-4$ & \\
\hline 10 & 1 & 2 & $2 \cdot 0$ & $4 \cdot 0$ & $3-6$ & 7 \\
\hline 15 & 6 & $3-4$ & 3.7 & 4.7 & $3-7$ & ] 6 \\
\hline 20 & 2 & $4-5$ & $4 \cdot 3$ & $5 \cdot 2$ & $4-9$ & 57 \\
\hline 25 & 4 & 4 & 4.0 & 6.0 & $4-9$ & 68 \\
\hline 30 & 3 & 5 & $5 \cdot 0$ & 6.5 & $4-9$ & 85 \\
\hline 35 & - & - & - & 6.9 & $4-9$ & 44 \\
\hline 40 ) & & & & $\pi \cdot 3$ & $5-9$ & 18 \\
\hline 45 & 13 & $6-8$ & $7 \% 0$ & $7 \cdot 3$ & $6-8$ & 4 \\
\hline $50-75$ & & & & 6.8 & $6-8$ & 15 \\
\hline
\end{tabular}

The similarity of the figures for both species at sizes $40-75$ is probably due to the fact that in the case of $A$. scabra we are at this stage dealing only with the fast-growing Dogger Bank specimens which, age for age, must approach in size the specimens of $A$. aspersa which have been examined. Neither species can be said to increase its average number of stigmata after a size of about $40 \mathrm{~mm}$. is attained. Unfortunately the table does not show features brought about by differences in growth rate in one area as compared with another. It is informative, for example, to take separately the results for those areas where a small maximum size (35 mm.) is attained by A. scabra. In Luce Bay and Loch Fyne individuals 7 stigmata per mesh are found at a size of only $15 \mathrm{~mm}$., whereas from all areas the average is below 5 . Again, at size $20 \mathrm{~mm}$., the average number is nearly $7 \frac{1}{2}$ as against an all-over average of just over 5. Not only is full stigmatic development reached in these areas at a relatively small size, but the high maximum number of stigmata of 9 is formed. This number is equalled elsewhere only in the northern Moray Firth, but 
is attained at the relatively larger size of $30 \mathrm{~mm}$. In the material examined the highest individual number of stigmata found was 10 (the figure 9 in the upper limits of the ranges of the above table indicating ranges of 8-10). For all the areas other than Luce Bay, Loch Fyne, and the Moray Firth the maximum number of stigmata found was slightly less8 or 9 -and was attained in each area at a size roughly proportional to the ultimate maximum size attained in that area. The effect of combining the Luce Bay, etc., figures with those from other areas has therefore been slightly to raise the mean number of stigmata attained at the lesser sizes, and may for comparative purposes be ignored since the numbers of individuals examined from the latter areas were by far the greater.

In the case of $A$. scabra we have probably dealt with collections including some specimens which had reached the maximum size attainable by this species. In that of $A$. aspersa, however, the largest animal was $76 \mathrm{~mm}$. in size, so that individuals up to fully half as large again remain to be examined. Whether the latter will exhibit a larger mean number of stigmata than 9 (the highest encountered in our material) seems doubtful. In justifying this opinion we may add information not revealed in the above table, which is a summary. At mean sizes of 40 , $45-75 \mathrm{~mm}$. the following were the ranges in the number of stigmata in the individual cases (in ascending order of size) : 7-8, 5-7, 6-8, 7-9, 5-9, 5-9, $7-9,7-9$. Thus the range as well as the mean number of stigmata remained practically stationary although the size of the animal increased to almost double.

The general inference from these results is that size for size (up to a size of about $35 \mathrm{~mm}$.) $A$. aspersa has, on the average, from 1-2 fewer stigmata per mesh than has $A$. scabra, and that in certain areas (e.g. Loch Fyne) where both species occur the difference may be rather more (3 or at most 4). In the general routine of distinguishing the species, however, little aid will be obtained from counting the stigmata.

$(\mathrm{H}$ and J) Number of Tentacles and of Internal Longitudinal Bars.These two characters are taken together since a relationship of specific value can be shown to exist between them. Little has hitherto been done with regard to enumerating the number of bars, and estimates of the number of tentacles have varied considerably, part of the variation being due to inaccurate observation, to which Herdman (12) calls attention. The method here adopted was to discard individuals which had been indifferently preserved (in the sense that the branchial aperture was closed by the sphincter muscles and the dissected-out tentacular collar so contracted that the tentacles could not be counted with at least $95 \%$ accuracy). The tentacles stain very well with very dilute hæmatoxylin so that even the most rudimentary ones can be easily seen and enumeration be made by turning each filament over with the needle under the 
binocular microscope. In certain cases (small individuals of $A$. scabra) it was necessary in order to secure a non-convolute piece of tissue to cut the collar into about 4 equal portions, and to make the count in each of the latter separately. Repeat counts should correspond to within the degree of accuracy stated above. In well-preserved material discards need seldom be made. The longitudinal bars were enumerated in a transverse direction in the right half of the branchial sac, immediately above the mouth.

The results of the counts made on the two species are plotted against size (Fig. 1). In A. aspersa the number of bars always outnumbers that of the tentacles (B. and T., Fig. 1). This, at least, is the case in specimens of $10 \mathrm{~mm}$. or more in size. Individuals from Islay and of size less than $10 \mathrm{~mm}$. showed a reversal of this relationship. (A series of size 5-9 mm. gave an average of 31 tentacles as against 28 bars.) Variation in locality has some effect in causing variation in the number of tentacles, since, size for size, Islay specimens were found to have formed more tentacles than those from Plymouth. The results from the Islay form are not included in Fig. 1, but in animals ranging in size from 10-20 mm. there occurred from 29-34 tentacles (av. 31-32), while at the higher size of 20-30 mm. from 28-43 tentacles (av. 34-35) were found. Thus the Islay form agrees in this character with the forms from Lochmaddy and Shetland (represented in Fig. 1), the number of tentacles being greater than that developed in the forms from Plymouth, Loch Fyne, and Ettrick Bay. (One specimen of size $56 \mathrm{~mm}$. from the last-named locality had 36 tentacles and 50 bars, ostensibly classing it with the Loch Fyne type.)

With regard to the number of bars, it was found that Loch Fyne and Ettrick Bay specimens had a slightly greater number than those of Plymouth, and a much greater number than those of Islay, Lochmaddy, and Shetland. The figures for the Islay forms may be given here since they are not represented in Fig. 1. From sizes $10-20 \mathrm{~mm}$. there were from 32-39 bars (av. 36-37), and from sizes 20-30 mm. from 36-42 bars (av. 40). In every case the number of bars exceeded that of the tentacles but not by so large a margin as in the other areas, which, it may be noted, agree in being less directly exposed to oceanic conditions. In another sheltered area-Loch Duich—one specimen of $37 \mathrm{~mm}$. was found with 54 bars (the tentacles could not be counted), and would apparently fall into the Loch Fyne class.

In the case of $A$. scabra (I-VI in Fig. 1) the number of tentacles is always greater than that of the bars - thus reversing the relationship found to hold for $A$. aspersa. For reasons of economy of space the results for the different areas have been grouped where similar. Thus I represents those for the North edge of the Dogger Bank as well as those for the Tail End of the Bank; II those for Luce Bay alone ; III those for the area E.S.E. of 
Aberdeen, as well as for Orkney and Shetland (Balta); IV those for the Firths of Clyde and Forth, for Islay, and for the area between Skye and Mull; V those for the Moray Firth alone; and VI those for the northern North Sea, for Scalloway (Shetland), for Loch Fyne and for Plymouth. The large dots represent the number of tentacles $(\mathrm{T})$, the small dots the number of bars (B), both plotted against size of animal. As was the case in connection with $A$. aspersa both the number of tentacles and of bars appear to increase with size of individual - this as a general rule-but, as was the case in the Islay, etc., forms of that species, the increase in number of tentacles is at most slight in I, II, and IV (in II also there is no obvious increase in the number of bars). The apparently fortuitous way in which areas (in some cases widely separated) gave sufficiently similar results to admit of the grouping of the latter in Figure 1 admits of no obvious explanation. Neighbouring areas, in which similarity of type might be expected to occur, as often as not exhibited dissimilarity of type. For example, the specimens from the two Dogger Bank areas, although agreeing in the size-number of bars relationship, disagreed to some extent in their respective number of tentacles, fewer being developed in those from the north edge. Again, in some areas the progressive increase (with size) in the number of bars or tentacles is much more rapid than in others. The fact of value to this investigation is, however, that a line can in every case be drawn to effect separation of the points representing the numbers of bars and tentacles respectively. The determination of the relative number of bars and tentacles therefore affords information of diagnostic value with regard to the two species. As these numbers appear usually to vary with size of individual no specific figures can be defined. The number of bars is much the same in both species (varying from 20-60 in A. aspersa and from 25-50 in A. scabra); but the number of tentacles varies from 10-40 in the former species and from $30-110$ in the latter.

A second distinction lies in the fact that, owing to their comparatively great numbers, the tentacles are in the latter species very much crowded at the base, whereas those of $A$. aspersa are set at intervals and appear to be slightly flattened to a broader base than those of $A$. scabra (Plate 6, Figs. 27, 28).

(K) The Shape of the Dorsal Tubercle (Plate 6).-The shape of the opening of the duct from the neural gland affords a further means of distinguishing $A$. aspersa from $A$. scabra. In the former species this opening is transversely oval or elliptical (broader than high); in the latter it is practically always higher than broad. In very small specimens of both species the opening is in the form of a more or less crescentic or incomplete loop (Figs. 1, 15, 16), although in $A$. aspersa the typically broadly-oval contour is often attained even in very young animals. Size 
IDENTIFICATION OF ASCIDIANS.
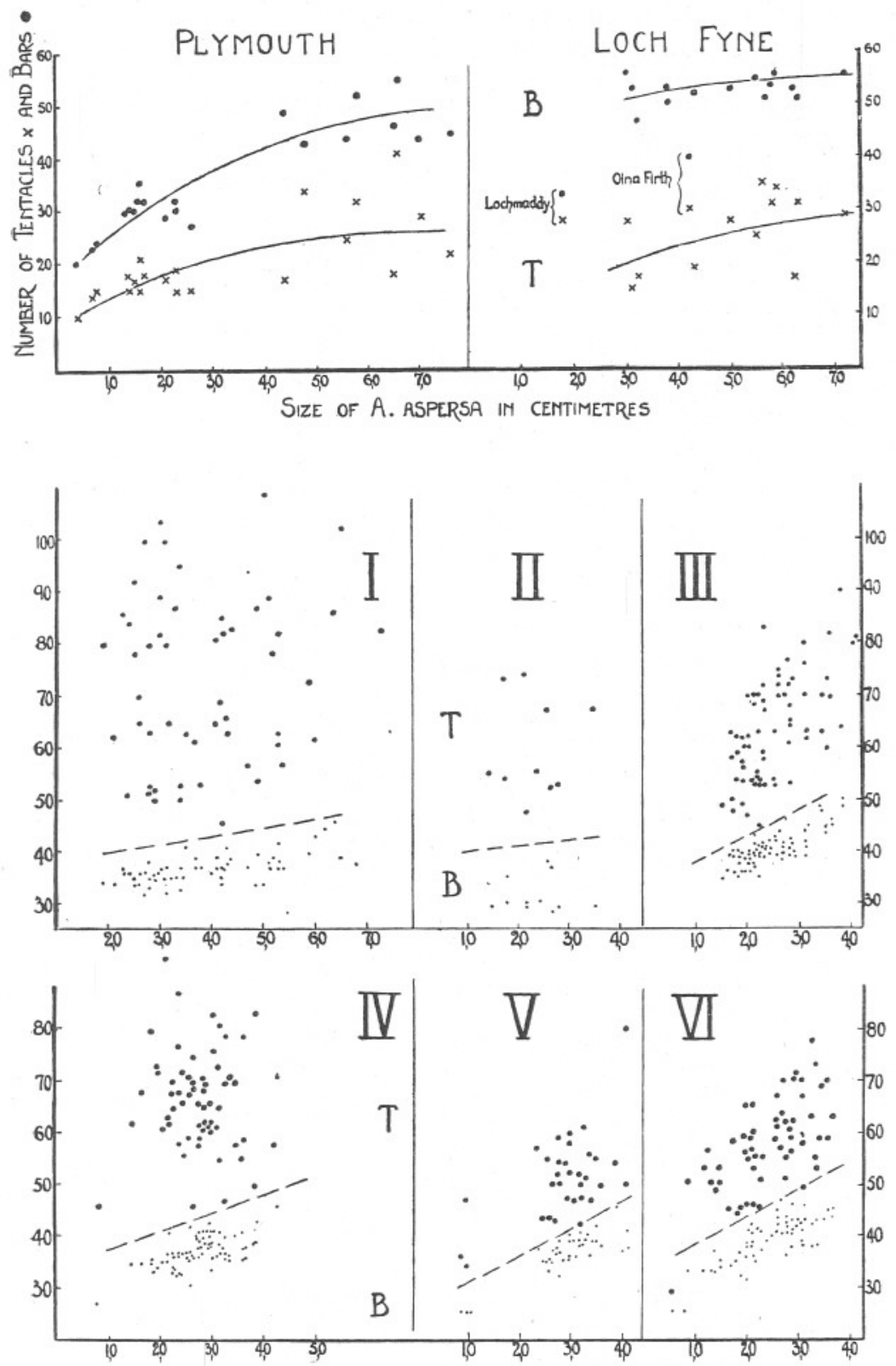

Size of A. Scabra in CENTIMETRES

(Explanation of I-VI in Text)

FIg. 1, 
for size of individual, the tubercle of this species is larger than that of A. scabra, and examination of 60 specimens showed :-

a. 46 cases with transversely oval tubercle with both horns incurved (Figs. 2, 3).

b. 4 cases with transversely oval tubercle with both horns turned right (Fig. 5).

c. 7 cases with cordate tubercle (about equally as broad as high), and both horns incurved (Fig. 4).

d. 3 cases with cordate tubercle, with the right horn only incoiled.

In A. scabra great variation of the fundamentally U- or longitudinallyelliptical form occurs. Of 310 specimens :-

a. 75 had tubercle simple U- or staple-shaped (Figs. 11, 18, 22, 25).

b. 56 had tubercle U- or flask-shaped with both horns outrolled (Figs. 7, $23,24)$.

c. 53 had tubercle U-shaped with both horns turned right (Figs. 10, 17).

d. 38 had tubercle U-shaped with only the right horn outrolled (Fig. 14).

e. 25 had tubercle broadly U-shaped with prolonged horns (Figs. 12, $20,21)$.

f. 23 had tubercle U-shaped with left horn inrolled (Figs. 6, 13).

g. 14 had tubercle U-shaped with right horn inrolled (Fig. 19).

h. 13 had tubercle U-shaped with both horns inrolled (Fig. 8).

j. 9 had tubercle almost cordate in shape (Fig. 4).

k. 4 had tubercle U-shaped with left horn outrolled (Fig. 9).

Thus only in a relatively insignificant number of specimens (j) was the cordate type of tubercle to be found, and to this extent slight confusion with two of the minority forms (c and d) found in A. aspersa is possible, although in the latter species the size of tubercle is greater. In $A$. scabra the U- or modified U-shaped tubercle is clearly predominant, and in each area there is a particular tendency towards some two or three of the forms. The most striking departure from the fundamental shape was exhibited (e) by many of the Dogger Bank specimens, in which the tubercle was larger than usual and had the horns elongated much as is the case in another species, $A$. obliqua.

(L) Distribution of the Renal Bodies.-In both of the species under comparison these bodies are large (as seen in Plate 8, Fig. 2) and, besides. being distributed over the mantle on the left side of the gut, extend also well beyond that region, whereas in other species of the Family Ascidiidoe they are usually said to be confined to the visceral region. This distinction between $A$. aspersa + scabra and the other species is probably specific if the phrase "well beyond " be used. (In A. prunum we have occasionally 
found the renal cells to extend slightly beyond the region of the viscera, and Herdman (12) has found this to be the case also in A. conchilega). Berrill has claimed it as a distinction between $A$. aspersa and $A$. scabra that the renal cells are more widely dispersed in the mantle of the former. In our material there has been little to choose in this respect between the two species. At times the cells are difficult to detect owing to their transparency, and the extent of their distribution might then be overlooked. This was the case particularly in the Loch Fyne material of both species. In the Plymouth material, on the other hand, the cells were particularly obvious. The degree of clearness with which the renal cells are seen probably depends upon the amount and colour of the concretions they contain.

(M) Size and Nature of the Eggs and Larva :-

a. The Eggs.-Except in the case of two species the eggs of the members of the Family Ascidiido were obtained in the aquarium, and are depicted in Plate 1 . In the cases of $A$. obliqua and $A$. prunum, however, living animals could not be obtained, and the size of the living egg was estimated from that of the ova in the terminal portion of the oviduct. (It was computed that the mean diameter of the living egg, one hour or so after expulsion, is on the average half as large again as that of the vitellus in the oviduct, most of the increase of size being due to the further withdrawal of the chorion from the vitelline surface.) Figures 7 and 9 are therefore included as showing, for comparative purposes, the probable sizes of the chorion in $A$. prunum and A. obliqua respectively.

It is important that the diameter of the recently expelled egg be that which is used for purposes of comparison, since some increase in diameter usually accompanies the development of the larva in the egg (Plate 2, Figs. 2, 3). The mean measurement of a number of eggs should, where possible, be used as a criterion, since at any one shedding period the eggs expelled are not of exactly the same sizes. Some difference in size may also be found if eggs from different regions, or eggs shed at different times of the year, are compared. It is of interest to note, however, that animals sent to Aberdeen from Plymouth, and kept in water from the sea off Aberdeen, yielded eggs differing in no way from those obtained from the same species in English Channel water. Slight differences of temperatures and salinity have therefore little or no effect on the structure of the egg. Certain species (A. scabra, Dendrodoa grossularia, Ciona intestinalis) which were kept in the aquarium over the winter season were found to yield eggs and larvæ even in March, although reproductive activity was in winter on a much reduced scale as compared with that in summer and autumn, when, incidentally, the largest eggs appear to be liberated. 
The egg of $A$. aspersa differs from those of the other species of Family Ascidiida in possessing, at the time of liberation, an investing layer of very large follicle cells (Plate 2, Fig. 1). There are from 28-32 of these seen in optical section. The chorion is not at this stage obvious, whereas it can be seen surrounding the ovum even in the oviduct of $A$. scabra. In the newly-liberated egg of the latter species the outer follicle cells are much smaller, resembling those of the eggs of the other species so far examined. From $70-80$ of them are seen in optical section and they form a layer over the chorion, which is quite clearly seen. The difference in the nature of the follicle cells can even be seen in groups of eggs dissected out from the terminal portion of the oviduct of each species (Plate 1, Figs. 10, 11). The difference in the size of the follicle cells, as Berrill states, is specific. Otherwise the eggs of these two species appear to agree in regard to diameter of vitellus and the nature of the cells which come to lie upon the surface of the latter.

Some time after the eggs of $A$. aspersa are set free the follicle cells separate to a greater distance from the ovum surface and are clearly seen to surround the chorion (Plate 2, Fig. 2). The result is that instead of being compressed owing to contiguity so as to present, in optical section, the appearance of a hexagonal network (Plate 2, Fig. 1), these large cells come to lie more or less free of each other (Fig. 2) so that they appear to be circular in optical section. Figure 1 represents an average size of egg of $\cdot 22-\cdot 24 \mathrm{~mm}$. and Figure 2 of from $\cdot 28-\cdot 31 \mathrm{~mm}$. The latter size persists unchanged for at least several hours, and may be taken as typical. The fertilised and developing egg (Plate 2, Fig. 3) may, however, be up to $.36 \mathrm{~mm}$. in diameter. It is interesting to note that the average diameter of eggs obtained from Plymouth and West Scottish specimens of A. aspersa was found to be identical (from $\cdot 27-\cdot 32 \mathrm{~mm}$.). As Berrill states the egg floats -in fact most of the eggs cluster together subjacently to the surface film of the water, and none is found further than one inch from the surface. This is not, however, the only species of Ascidian forming eggs displaying this character. Specimens of Corella parallelogramma taken in the Firth of Clyde and kept under observation on board ship yielded within a few hours similar but slightly smaller eggs (Plate 1, Fig. 8). These had a diameter of about $\cdot 18 \mathrm{~mm}$. at the time of liberation, and of from $\cdot 24-\cdot 26 \mathrm{~mm}$. one hour later. The eggs of $A$. scabra, however, do not rise to the water surface, remaining at or near the bottom of a jar containing them. At liberation they have the diameter and form which is maintained for many hours afterwards (Plate 1, Fig. 5 ; Plate 2, Fig. 4). It cannot be said that the chorion diameter differs materially from that of the eggs of $A$. aspersa, but this statement is made with reservation, since we have found that variation apparently arises if observations be 
continued from season to season and upon individuals from different localities. The following variation in diameter has been found :-

Off Aberdeen, June. Size $\cdot 32-\cdot 36 \mathrm{~mm}$. Average $\cdot 33 \mathrm{~mm}$.

Off Aberdeen, Oct. Size $\cdot 27-\cdot 31 \mathrm{~mm}$. Average $\cdot 29 \mathrm{~mm}$.

Off Peterhead, June. Size $\cdot 34-37 \mathrm{~mm}$. Average $\cdot 345 \mathrm{~mm}$.

Off Plymouth, June. Size $\cdot 30-33 \mathrm{~mm}$. Average $\cdot 32 \mathrm{~mm}$.

Off Skye, August. Size $\cdot 28-\cdot 30 \mathrm{~mm}$. Average $\cdot 29 \mathrm{~mm}$.

Off N. Scottish Coast, Sept. Size $\cdot 29-30 \mathrm{~mm}$. Average $\cdot 295 \mathrm{~mm}$.

Firth of Clyde, Aug: Size $\cdot 31-32 \mathrm{~mm}$. Average $\cdot 315 \mathrm{~mm}$.

As Berrill figures an egg of only $c a .0 .25 \mathrm{~mm}$. diameter from the Swedish coast and one of $c a \cdot 0 \cdot 40 \mathrm{~mm}$. from the English Channel, it appears that even greater variation is possible. We have not, however, found any distinction in this character between erect and recumbent forms from the same area.

The conclusion is that A. aspersa may be distinguished from $A$. scabra and from all other species of Family Ascidiida by the nature of the outer follicle cells of the egg, and that this distinction may be effected even by dissection of the oviduct of the preserved mature animal. (In our material Scottish specimens of 29 and $31 \mathrm{~mm}$. in length were found to be mature, while those in the region of size $24 \mathrm{~mm}$. were immature. Berrill gives the size at first maturity as being not less than $40 \mathrm{~mm}$. in the case of English Channel specimens.)

At the lower limit of its size-range the egg of $A$. scabra is not clearly to be differentiated from the eggs of $A$. mentula and $A$. mammillata. The two later species along with $A$. conchilega form relatively small eggs, viz :-

A. conchilega (Plate 1, Fig. 3). Diameter of egg ca. $0 \cdot 22 \mathrm{~mm}$.

A. mammillata (Plate 1, Fig. 4). Diameter of egg ca. $0 \cdot 23-0 \cdot 25 \mathrm{~mm}$.

A. mentula (Plate 1, Fig. 1). Diameter of egg ca. $0 \cdot 24-0 \cdot 27 \mathrm{~mm}$.

Again at the middle or upper portion of its size-range the egg of $A$. scabra might be confused with those of and

A. prunum (Plate 1, Fig. 7). Diameter ca. 0·31-0·32 mm. (estimated),

A. virginea (Plate 1, Fig. 2). Diameter ca. 0·34-0·35 mm.

All these species form eggs with relatively small outer follicle cells. The largest egg is evidently that yielded by $A$. obliqua, and, judging from the size of the ovum in the duct, must reach $.50 \mathrm{~mm}$. in diameter (Plate 1, Fig. 9). In this case also the outer follicle cells are small, but the size alone would apparently be a feature of diagnostic value.

In view of the new scheme for the classification of Family Ascidiida suggested below, notice may be directed here to the fact that the eggs of NEW SERIES.-VOL. XVIr. No. 1. SEPTEMBER, 1930. 
A. mentula, conchilega, and mammillata are very alike, and are the smallest formed in the Family. Examination of further material is, however, desirable to determine the precise limits of variation in the diameter of the eggs of these species, none of which, either on board ship or in the aquarium, freely shed their ova.

In passing it may be mentioned that, as is shown in Plate 2 (Figs, 5, 6), the rupture of the chorion by the larva appears, in this Family, to occur at a point opposite the anterior portion of the tail of the larva, this portion serving as a fulcrum for the stressing convulsive movements of trunk and tail.

b. The larva.-From $A$. aspersa and $A$. scabra from various regions larvæ were easily and repeatedly obtained. Only a few were, however, secured from $A$. mentula and A. mammillata, and none from A. conchilega and $A$. virginea. Two or more adult individuals of a species were maintained in the same jar. No attempt was made to obtain larvæ by means of artificial fertilisation. In Plate 3 there are represented the larvæ of the first four of the above-mentioned species. Save in Figures 1 and $3 \mathrm{a}$ the hyaline ectodermic mantle is omitted. The view of the subjects is such that only in Figure $3 \mathrm{a}$ are all three anterior adhesive papillæ shown, while Figures 2 and 5 show larvæ not long after the escape of the latter from the egg, so that the papillæ are more or less repressed, as they appear in the egg (Plate 2, Figs. 3, 5, 6). It is however obvious that the papillæ are, in all four species, of a short, truncated cone-like form. Allowing for the fact that in Figures 3, 4, and 5 the larvæ are viewed from the right side, while in Figures 1, 2, and 3a they are seen from the left (in Fig. 1 rather obliquely), it seems that there is no essential difference in any one species, as compared with another, in the relative positions of otocyst and eye in the cerebral vesicle. In some of the figures of Plates 2 and 3 , however, different stages of notochordal development are shown. In the case of A. scabra (Figs. 3 and $3 a$ of Plate 3 , and Fig. 5 of Plate 2) the sheath of the notochord surrounds a hyaline core, and this is the only stage which we have observed in the larvæ of this species. In A. aspersa (Plate 2, Fig. 3), however, both in the developing larva in the egg and in the newly-hatched larva, the hyaline substance is restricted to an ordered series of biconvex discs. The latter are formed originally, according to Kupffer (13), from " refringent particles " appearing in the plasma of the cells of the notochord, and increase in size, finally uniting (in Fam. Ascidiida) to form a more of less elastic hyaline axis. In $A$. aspersa, A. mentula, and A. mammillata, so far as we have observed, the latter stage is not attained until some time after the larva has been free, whereas in A. scabra it occurs even prior to hatching, although the hyaline axis may be discontinuous in places-i.e. broken up into several rod-like portions, this probably being an intermediate stage to complete fusion. 
There is thus no readily to be observed essential difference in the structure of the larvæ, save perhaps with regard to stage of notochordal development at hatching, and this point is worthy of further investigation. There remains to be considered the question of larval size. Here again, as in the case of the eggs, there is apparently some slight seasonal as well as regional variation.

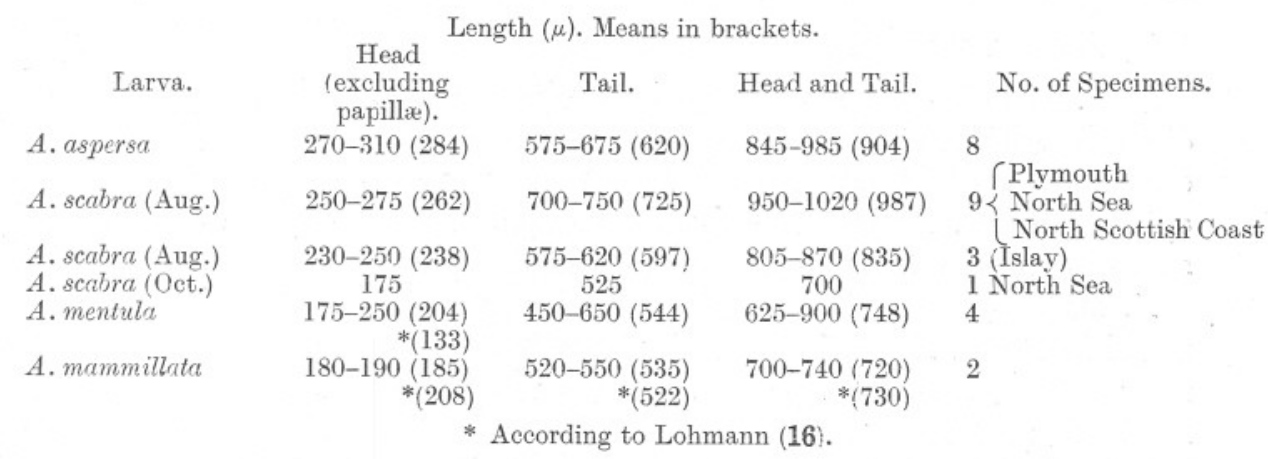

From these data it is obvious that the dimensions of the larvæ of A. scabra vary sufficiently to cover almost completely the range of variation in size of larva in the other three species. Probably the only safe deduction is that the larvæ of $A$. mentula and $A$. mammillata are rather smaller than those of $A$. aspersa and A. scabra.

\section{Conclusion.}

The foregoing investigation of the features of $A$. aspersa and $A$. scabra clearly establishes the fact that, by means of certain of these features, these two forms can always be distinguished from each other. The specific points of difference are found in (1) the relationship holding between number of tentacles and longitudinal vessels and (2) the nature of the egg. Almost, but not absolutely specific, are the differences in the following characters: (3) shape of the dorsal tubercle; (4) average size ; (5) nature of test, and (6) position of the atrial aperture relative to the branchial aperture. The following are features of less specific value : (7) geographical and bathymetric distribution and (8) extent of area of attachment to the substratum. Little or no specific value can be attached to (9) colour; (10) number of stigmata per mesh of the branchial sac; (11) distribution of the renal cells, and (12) size and structure of larva (if the possible more rapid notochordal development in $A$. scabra be excepted).

Characters which did not in this case appear to call for special investigation were the nature of the musculature in the mantle and the details in connection with the alimentary tract, the dorsal lamina and the gonads. 
Any or all of these characters might, however, be of specific importance where other species are concerned.

\section{Variation in other Species of Family Asciditd}

A less extensive material relating to these well-defined species was examined.

(1) Ascidia mentula.

From 35 collections of this species 53 individuals were selected for dissection. This material was obtained from various parts of the Scottish coast between the Moray Firth and Loch Fyne, over a general depth range of 17-60 metres. No justification was found for differentiating the results according to area, and they are here presented in combination.

A. mentula, along with the remaining species of the Family, is distinguished from $A$. aspersa and $A$. scabra by the possession of typical free papillæ on the branchial sac. This is a constant feature, and need not be further dealt with. Along with $A$. conchilega and $A$. mammillata this species can be distinguished from $A$. virginea, $A$. obliqua, and A. prunum by having the branchial sac prolonged behind the viscera. This feature also is constant. From A. conchilega it has been distinguished on account of having the nerve ganglion situated on the mantle at a point distant from the dorsal tubercle by about one-fourth (as compared with one-sixth) of the body-length, by possessing small instead of large renal cells, and a smooth as compared with a papillate test surface. Secondary branchial papillæ have been stated constantly to occur, whereas in A. conchilega they may occasionally be absent. These points of distinction therefore require special investigation. From A. mammillata the species is sufficiently distinguished by the occurrence in the latter of a recurved branchial sac and a peculiar modification of the dorsal tubercle.

(A) Distribution. $-A$. mentula resembles $A$. aspersa in that while it extends northwards along the west Scottish coast (being found even in the northern part of the Moray Firth), it is generally absent from the east coast of the British Isles.

(B) Size.-From 5-18 cm. in length.

(C) Attachment.-This is usually effected by means of a small area at the left posterior part of the body. There are however all variations from this slight attachment to complete fixation by the side or even, in a crevice, by a portion of both sides. In our material 3 specimens were attached by almost the whole side, 8 by from two-thirds to three-fourths, 12 by rather more than one-half, 9 by one-half, 4 by rather less than one-half, and 17 by about one-third of the side. (Two of the latter were attached not basally, but by a section of the mid-portion of the side.) As 
has been the case with regard to other species, differences in mode of attachment have in the past been made part of the basis for splitting this clearly-defined species into several species (see, e.g. Alder and Hancock's monograph, in which 8 species and 1 variety, all referable to $A$. mentula, were described).

(D) Colour.-This varies from a horn-coloured or milky white tint in young specimens to a much darker tint in older specimens, which range in colour from greenish white through red to dark brown.

(E) Test.-This is thick, cartilaginous, and smooth in young individuals, but becomes more or less wrinkled or roughly furrowed (though not tuberculated) in older animals.

(F) Position of Apertures.-The atrial aperture is usually described as lying at a point distant from the branchial by from one-half to twothirds of the body-length. In the specimens dealt with here, however, the interval was rather less than one-half in a minority of 9 cases. Of the remainder 10 showed an interval of one-half, 32 of rather more than one-half and only 2 of two-thirds.

The results in the case of $A$. conchilega, which rather resembles A. mentula in this character, may be given here. Out of 16 specimens, 4 showed an interval of rather less than two-thirds, 7 of rather more than one-half, 3 of one-half, and 2 of rather less than one-half. These two species therefore agree with regard to this feature, and may by its means. be distinguished from all the other common species of Family Ascidiidas. except $A$. mammillata.

(G) Branchial Stigmata.-The number of stigmata per mesh of the branchial sac of $A$. mentula is usually given as being 6 or 7 . Counts made on the above material showed that specimens from the region N. Moray Firth-Orkney possessed from 4-7 stigmata between sizes 4-8 cm., and from $5-8$ between sizes $8-18 \mathrm{~cm}$. There was thus an increase of only one slit in the larger as compared with the smaller sizes. Individuals from the N.W. and W. Scottish coasts possessed from 4-6 and 4-7 slits in the smaller- and larger-sized animals respectively. That is, accompanying increase of size, there was practically no increase in number of stigmata. In this species therefore it seems that the number is fairly constant (4-8) and that there is little increase with increasing size of individual. Slight differences may arise with change of area since the individuals of the Orkney region appear consistently to form about one more slit per mesh than do those of the west coast.

(H and J) Number of Tentacles and Longitudinal Vessels.-A. mentula is generally recognised as having from 20-80 (mostly about 40) tentacles. In our material the number was found to vary from 33-100 in individuals ranging in size from $4-18 \mathrm{~cm}$. The average number was about 65 . All rudimentary tentacles were as usual included in the counts. The number 
of tentacles did not obviously increase with increasing size of animal. The number of bars did, however, so increase. Thus if number be plotted against size as in Figure 1 the loci fall in the neighbourhood of a curve rising gently from a point representing about 64 bars (at size $4 \mathrm{~cm}$.) to one representing about 90 bars (at size $18 \mathrm{~cm}$.). The entire range of number of bars is from $60-105$.

(K) Shape of Dorsal Tubercle.-In descriptions of this species the tubercle is usually said to be irregularly rounded or horse-shoe shaped. Of the specimens dissected 47 out of 51 could be said to possess U-shaped tubercles. Of these 15 had the left horn and 11 both horns incoiled. These are evidently the usual shapes formed in Scottish waters. Of the remainder 8 were simply U-shaped, 7 had the right horn incoiled, 3 the left horn turned outwards, 2 both horns turned left, and one both turned out. It is noteworthy that a minority of 4 tubercles were (as is typically the case in A. aspersa) broadly ovate, with both horns incoiled.

(L) Distribution of the Renal Bodies.-These cells are of moderate size and form a coating over the viscera.

(M) The size and nature of the eggs and larva were discussed under A. aspersa and A. scabra.

Reference remains to be made to two characters which are used to form part of the means of distinguishing $A$. mentula from A. conchilega.

(N)-Although in the first-named species there are almost always, and in the latter rarely, secondary papillæ lying between the primary papillæ of the branchial sac, the distinction is liable to fail unless a large tract of the sac be examined.

(O) - On the other hand, the relative distance of the dorsal tubercle from the ganglion (this distance being expressed as a fraction of bodylength) may definitely be used as a specific point of difference between these species. For A. mentula the fraction is usually stated to be onefourth, and in the 51 specimens examined an average of 0.26 was obtained. The lower and upper limits were, however, $0 \cdot 17$ and $0 \cdot 37$. In A. conchilega the variation was found to be from $0 \cdot 10-0 \cdot 18$ (average $0 \cdot 14$, or one-seventh, as compared with one-sixth found by previous workers). There is thus practically no overlap into the range of variation found for A. mentula.

\section{(2) Ascidia conchilega.}

Out of 25 separate collections of this species 16 specimens only were taken for dissection. The latter were obtained from the northern North Sea, the Faroe-Shetland Channel, the Minch and Eddystone, being taken in depths ranging from 98-229 metres.

(A) Distribution.- This is not yet very fully known, but appears to resemble that of $A$. mentula, though with a rather more northerly bias. Although the lower depth limit has hitherto been regarded as being 
360 metres, this species has occurred in a recent Scottish Collection from a depth of 1104 metres in the Faroe-Shetland Channel, whence it has not hitherto been obtained.

(B) Size.-The specimens here dealt with ranged in size from $10-45 \mathrm{~mm}$., but a size of $55 \mathrm{~mm}$. has been recorded. The species may therefore readily be distinguished from $A$. mentula, which is seldom taken at a size of less than $55 \mathrm{~mm}$.

(C) Attachment.-In 14 of these specimens the attachment was by almost the complete side, and in one individual by the complete side. In the remaining case, however, less than half of the side was fixed. This species is described as being fixed by the whole length of the left side, and this is probably usually, though not invariably, the case.

(D) Colour.-There is no obvious pigmentation. The animals have a more or less pale greenish tint.

(E) Test.-This is rather thin and cartilaginous, and has numerous minute tubercles on the free surface.

(F) Position of Apertures.-This has been dealt with under A. mentula.

(G) Number of Stigmata in a Mesh of the Branchial Sac.-In animals of size $10-13 \mathrm{~mm}$. this number was from 2-3, but rose to from 3-4 at size $15-28 \mathrm{~mm}$. and to from 5-7 at size $34-46 \mathrm{~mm}$. The number therefore tends to increase as the individual grows.

(H, J) Relative Number of Tentacles and Longitudinal Vessels.-The number of tentacles was found to vary from 44-125, and did not appear to be dependent on the size of the animal. There are in these species three distinct rows of tentacles of different size-a feature absent from or not so clearly seen in the other species of the Family.

On the other hand, the number of bars was found to increase steadily with the size-from about 34 at a size of $10 \mathrm{~mm}$. to about 54 at a size of $45 \mathrm{~mm}$.

(K) Shape of Dorsal Tubercle.-In this species the tubercle is almost always horse-shoe shaped. Modifications of this simple fundamental shape are practically absent. In one individual, however, the right-hand horn of the tubercle was found to be incoiled, and in another the horns were prolonged.

(L) Renal Bodies.-These are particularly large and obvious, though of varying degrees of transparency. They are practically confined to the region of the viscera. Their arrangement over the stomach often imparts a ridged appearance to that organ.

(M) Eggs and Larva.-The egg of this species was described under A. aspersa. The larva was not obtained.

It is seen that $A$. conchilega may easily be distinguished from $A$. mentula by determination of the nature of the following characters: Bathymetric distribution, test, distance of dorsal tubercle from nerve ganglion, size 
of renal cells, frequency of occurrence of intermediate papillæ in the branchial sac, and number of longitudinal bars (in the former species only about 54 occur at a size of $45 \mathrm{~mm}$. ; in the latter 64 at a size of $40 \mathrm{~mm}$.).

Differences in the shape and course of the gut are not discussed here, since the latter is often obscured by the overgrowth of renal bodies and gonads. Features of little or no specific use in separating these species are the nature of the attachment, the colour, the relative distance apart of the apertures, the number of gill-slits and tentacles, the shape of the dorsal tubercle, and the size and structure of the egg. In cases, however, in which the number of tentacles exceeds 100 the probability will be that a specimen of $A$. conchilega is being examined.

\section{(3) Ascidia mammillata.}

This species is easily identified. It has been recorded from as far north as the Clyde Estuary but has not recently been found there. With the exception that its northerly limit is probably the region Irish Sea-Firth of Clyde, this species is distributed over much the same area as is A. mentula. Three specimens from Plymouth were dissected. The surface of the test is mammillated, and this feature, added to those of the reflexed branchial sac and the peculiar structure of the dorsal tubercle, sufficiently distinguishes the species. The dorsal tubercle proper is a scarcely to be discerned gutter-shaped opening, very far distant from the nerve ganglion. More prominent, however, are the very numerous bright orange secondary openings situated all along the course of the neural canal.

The following are other features of the species, with the relative observations (in brackets) made upon the three specimens: Size from

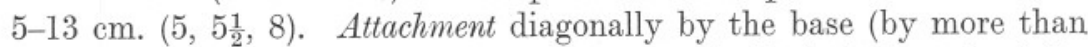
one-third, by one-half, and by more than one-half of the length of the side). Colour of test opaline white or yellow, of mantle dark pink to blue. Apertures (atrial nearly one-half of the body-length distant from the branchial). Number of stigmata per mesh (from 5-7 in these mediumsized specimens). Branchial papilla (as in A. mentula). Tentacles-of three sizes, and about $48-60$ in number $(56,74$, and at least 65 were counted in these specimens); the number of longitudinal bars was 78 , 87, and 102 respectively, and appears therefore to increase with size of animal ; the egg and larva have already been referred to ; the renal cells are abundant but confined to the visceral region.

Of these features only one - the colour of the mantle-can be said to distinguish this species from $A$. mentula, which is the only form likely to be confused with it.

There remain to be considered three boreal species of Family Ascidiida. These are distinguished from (1), (2), and (3) by having no prolongation 
of the branchial sac beyond the viscera; further, the dorsal tubercle lies close to the ganglion, and the apertures are not more than one-third of the body-length apart. In all three of these characters they resemble A. aspersa and A. scabra, from which they differ in having real free papillæ in the branchial sac.

\section{(4) Ascidia obliqua.}

From 18 separate collections of this northerly deep-water species 33 specimens were taken for dissection. Of these 8 were from the FaroeShetland Channel and 25 from Faroe.

(A) Distribution.-Like A. prunum, this species is limited to Arctic and north Boreal regions, but may extend its range slightly into northern British waters by way of the deep channels whose water is partly of Aretic origin. The record given by Herdman (8) from Lamlash Bay, Firth of Clyde, should probably have been referred to another species. (We have found in a collection from Ettrick Bay an individual of $A$. conchilega which rather resembled $A$. obliqua outwardly.) Both $A$. prunum and $A$. obliqua extend their range into deep water, the former to nearly 400 metres' depth, and the latter (according to a new Scottish record from the Faroe-Shetland Channel) to 1250 metres. A. obliqua may in fact be said to be the northern deep-water counterpart of $A$. scabra, being quite the commonest Ascidian species in, e.g., that Channel. A. virginea is distinguished from these two more northerly species by having a south-Boreal distribution (from the Mediterranean to Faroe). That is, it is commoner in the south, and solitary specimens only are to be taken from the northern North Sea and the coastal waters of west Scotland.

(B) Size of A. obliqua.-From 25-75 mm. The individuals dealt with here ranged in size from $30-73 \mathrm{~mm}$.

(C) Attachment.-A. obliqua is attached rather diagonally by a large circular area which includes the base and part of the left side. When removed from the water the animal, which has a flaccid body, sags down around this base. This is a distinguishing feature of the species.

(D) There is no pronounced pigmentation, the test being merely horncoloured, though occasionally somewhat rugose in older individuals.

(E) The test is fairly thin and soft, with smooth or wrinkled surface. The species often adheres loosely to other Ascidians.

(F) The apertures are set not far apart upon conical and rather deeply lobed tubes. In the specimens examined their distance apart was onethird of the body-length in 19 cases, rather more than one-third in 10 cases, and rather less than one-third in 4 cases.

(G) The number of stigmata per mesh of the branchial sac is usually stated to be from $3-6$. In the above material the number was from 
3-5 in the smaller and from 4-6 in the larger specimens. There are no intermediate papillæ in the sac of this species.

$(\mathrm{H}, \mathrm{J})$ The number of tentacles varied from about 30-75, and apparently rises for some time with increasing size of individual, but becomes more or less constant after a size of about $50 \mathrm{~mm}$. is attained.

The number of longitudinal bars increased gradually with the size of the animal from a minimum of about 65 (at size $30-50 \mathrm{~mm}$.) to a maximum of about 104 (at a size of from $40-70 \mathrm{~mm}$.).

(K) The dorsal tubercle is very large for the size of the animal and was found always to be elongate-U-shaped. The horns are prolonged but never coiled to any great extent. This is one of the species in which the size and shape of the tubercle are distinctive.

(L) The renal cells are not large. They are finely felted over but not beyond the visceral region.

(M) The egg of the species is, as has been stated above, probably the largest of any formed by the species of Family Ascidiida.

The larva has not been obtained.

(5) Ascidia PRUnum.

This species is at best rare even in north British waters. It has been taken by Scottish research vessels only off the coast of Iceland. From the collections from that coast 3 specimens only were examined for the purposes of this investigation. These were from $10-45 \mathrm{~mm}$. in length, but a size of $70 \mathrm{~mm}$. can be attained by this species. The attachment was by almost one-half of the left side in two of the cases and by the whole side in one. The apertures were separated by a distance equal to rather less than one-third of the body-length in two individuals, and rather greater than one-third in one individual. The test, as in A. obliqua, is usually thin and semi-translucent, but is never flaccid, and may become moderately thick. In young individuals the surface is smooth, but later it becomes a little wrinkled. Minute papillæ may be present. In the branchial sac intermediate papillæ are almost always present. There are stated to be from 3-5 stigmata per mesh of the sac in smaller and from 6-7 in older animals. (In these three specimens rather more were found, viz., from $5-6$ at a size of $10 \mathrm{~mm}$. and of $35 \mathrm{~mm}$., and from $7-8$ at a size of $45 \mathrm{~mm}$.) The number of tentacles is usually given as being about 50, of three sizes. (In these specimens the number varied from 17 in the smallest to approximately 95 in the largest individual, and probably increases with size of animal, at least for some time.) The number of longitudinal bars rose similarly from 19-73 (from 40-70 is the range of variation given in the descriptions by other workers). The dorsal tubercle in its simplest form is merely a crescent-shaped slit, but it may also be half-moon or horse-shoe shaped. In the latter case one or both 
horns may be bent inwards. Large renal bodies are distributed over the region of the viscera and may even extend slightly beyond the latter.

A. prunum therefore differs from $A$. obliqua in being more completely attached, and in the nature of the test and habit. The renal cells are larger, but the egg is probably smaller than in the latter species. The dorsal tubercle is smaller and of different shape. There are fewer longitudinal bars in the branchial sac, in which, however, intermediate papillæ are present.

Features of little or no distinctive value are the geographical distribution, the size, the colour, the distance apart of the apertures, and the number of stigmata and of tentacles.

\section{(6) Ascidia virginea.}

This species is rather rare. Out of 12 collections containing it we have taken only 8 specimens for dissection. Three of these were obtained from Plymouth and 5 from points on the west Scottish coast between the Clyde and Shetland. The total size-range was from 27-58 mm., but this species can reach a size of $75 \mathrm{~mm}$. In shape the body is elongatequadrilateral, tapering slightly towards the anterior end. In one specimen from Shetland the test was produced into a stalk, with the result that the animal was pear-shaped. One Plymouth specimen was attached by the entire side to a shell. This modification of the usual basal form of attachment has not, as far as we are aware, been hitherto observed, and forms an analogy with the depressed forms of A. aspersa, A. scabra, and $A$. mentula. Of the other specimens 6 were attached basally and one by two-thirds of the left side. This species is usually capable of being identified by the nature of the test, which is glabrous, rather gelatinous in texture, semi-transparent, and of a delicate pinkish hue. The apertures are quite sessile, the atrial aperture lying at a distance of rather less than one-third of the body-length from the branchial. (In 5 cases the interval was less than one-third, in 2 it was one-third, and in one-the depressed form-rather more than one-third.) In the meshes of the branchial sac the number of stigmata is stated as varying from 6-8. In our specimens the number ranged from 4-6 in the smaller and from 6-9 in the larger individuals. The crowded tentacles are often extremely difficult to count, especially since there are many minute ones. The number found exceeded that usually quoted, there being about 60 of the first order and probably about an equal number of a lesser size, some of which are mere papillæ on the tentacular collar. The minimum number of tentacles is probably about 60 , and the maximum upwards of 120 , but there is no obvious increase in the number as the size of the animal increases. As is more usual, however, the number of longitudinal bars 
does so increase, regularly in the case of this species from about 35 at a size of $27 \mathrm{~mm}$. to about 54 at a size of $58 \mathrm{~mm}$. The dorsal tubercle is simply U-shaped (in two cases, however, the left horn was incoiled and in one the horns were prolonged after the fashion of those of the tubercles of $A$. obliqua and the Dogger Bank specimens of $A$. scabra). The renal bodies are not prominently seen. Secondary papillæ are rare or rudimentary in the branchial sac. The egg is moderately large.

The chief features distinguishing $A$. virginea from $A$. obliqua and A. prunum are therefore the nature of the distribution, of the test, and of the shape of the body. The number of longitudinal bars is more restricted. An additional distinction lies in the shape of the gut, since in this species the anal portion runs directly forwards so that the anus is considerably higher than the uppermost portion of the loop of the intestine (Plate 7, Fig. 4). In the other two species the anus is at approximately the same height as, or is actually lower than, that portion of the intestine.

A. TRITonis (Herdman, 1883), the remaining Boreal species of Family Ascidiida, has been recorded from various parts of the slope of the N.W. European continental shelf, viz., to the south-west of Ireland and of Faroe and to the south of the Wyville-Thomson Ridge, at depths ranging from 840 to 1210 metres. It has not occurred in recent Scottish collections from either slope of the latter Ridge, and appears to be confined to very deep water in a limited area. As described by Herdman (9) and by Hartmeyer (7), this form would appear to have many features in common with $A$. conchilega. It reaches a much greater size, however, the range being from $5-17 \mathrm{~cm}$. It is noteworthy that our new record of $A$. conchilega from a depth of 1104 metres does away with any absolute bathymetric distinction being made between the two species. This record was made, however, in the Faroe-Shetland Channel, on the north (or cold-water) side of the Ridge, where the temperature is below zero, whereas the temperature was found to vary from $5 \frac{1}{2}-8 \frac{1}{2}{ }^{\circ} \mathrm{C}$. on the south side of the Ridge whence $A$. tritonis has been obtained. It is suggested here, nevertheless, that proof is required that the latter species is not merely a large form of A. conchilega. Hartmeyer, from a study of about 50 specimens of the former species, revised Herdman's description. The outstanding features appear to agree in most details with those of the latter species. The branchial sac extends beyond the gut, the course and appearance of which, judging by Herdman's illustration, agree with those found in A. conchilega. The ganglion is separated from the dorsal tubercle by a distance equal to approximately one-sixth of the body-length. There are small papillæ on the test, which is cartilaginous in texture. The 
attachment is by from one-half to two-thirds of the left side, and the atrial aperture is separated from the branchial by a distance equivalent to from rather less than one-half to two-thirds of the body-length. There are about 3 stigmata in a mesh of the branchial sac of smaller, and 5 in the sac of larger individuals. (The number in A. conchilega rises to a maximum of from 5-7, so that here there may be a point of difference.) Branchial papillæ are present but secondary papillæ are absent. (In A. conchilega the latter are occasionally present, but we have found that this is not quite a specific feature, since the formation of secondary papillæ is - in some species at least-the prelude to the formation of transverse vessels between them, with the result that the original mesh is divided transversely into two meshes. In other words, the more fully developed the branchial sac is - e.g. in A. mentula, whose sac may or may not show secondary papillæ of a lesser size than primary - the less chance there is of finding in it intermediate papillæ.) The tentacles are very numerous - from $80-100$ or more. The number of longitudinal bars exceeds 100 . In $A$. conchilega the number rose steadily with size of animal to about 54 at a size of from $4-5 \mathrm{~cm}$., and might conceivably be much greater in individuals of double or treble this size. In this species, as in $A$. tritonis, the dorsal tubercle is simply horse-shoe shaped, with rare modifications.

We found that in $A$. conchilega, while the number of tentacles did not appear to be dependent on the size of the animal, the number of bars did so. This would account for the agreement in the number of tentacles of the two species and the disagreement in the number of bars. The presence or lack of intermediate papillæ in the sac may prove to be a constant and specific feature whereby these species may be distinguished. Beyond this and the slight difference in number of branchial stigmata per mesh there seems to be little to go upon other than the difference in the maximum size which the animals may attain. It would apparently be very difficult to state to which species individuals of, e.g., $5 \mathrm{~cm}$. in length belonged.

From the Key to the Boreal Ascidiida given below A. tritonis has been omitted for these reasons and since the form is not likely to be encountered in water of moderate depth.

\section{A Suggested Key to the Boreal Species of FAMILY Ascidinde.}

It is hoped that the foregoing does something to bring into clearer prominence those features which may reliably be used in the classification of the species of this Family. Our experience has been that in nearly every case the species can be recognised from its external appearance. That is, the number of possibilities is first of all narrowed down by such 
a character as the distance apart of the apertures (the corollary of which in internal structure is the distance apart of nerve ganglion and dorsal tubercle) ; it is further narrowed down by consideration of the nature of the test and the habit. The size of the animal and its mode of attachment to the substratum are of less importance, and little reliance need be placed on the colour. The ability to identify a species from its external appearance is, however, and must remain, the outcome of knowledge gained by dissection of most if not all of its forms of variation-including variation in size, which may or may not entail variation in such characters as the number of tentacles and longitudinal bars, of the stigmata in a mesh in the branchial sac, and even in the presence or absence of secondary branchial papillæ. Internal evidence of first importance is afforded by the presence or absence of a prolongation of the branchial sac behind the region of the viscera, and of true papillæ in the sac. The shape and position of the dorsal tubercle are of importance in certain cases, but variation in the former character often occurs. Importance can seldom be attached to pigmentation of the mantle. The shape of the gut is often largely obscured by overgrowth of gonads and renal cells, but the terminal portion of the intestine can easily be seen, and its course and relative position afford in certain cases evidence of specific value. The size and distribution of the renal cells, while aiding an identification to be confirmed, are not of primary importance, and in this Family a study of the nature of the gonads-organs whose appearance is subject to change with season and with size of animal - is unnecessary for purposes of identification. Much information still remains to be gathered with reference to the precise limits of geographical and bathymetric distribution of certain of the species. In addition the developmental characters require further study ere full use can be made of them for systematic purposes.

It is suggested that the three existing genera of Family Ascidiida may be combined without entailing increased difficulty in the identification of the species or failure to give due weight to the known structural or developmental characters. The Family is not crowded with species, and the present division into genera is not a natural one. Genus Phallusia has been established to include a species to be distinguished from the others of the Family by having a modified type of dorsal tubercle and a reflexed portion of the branchial sac. But, as has been shown, this species resembles $A$. mentula and $A$. conchilega, and differs from the other species of the Family in having the branchial sac produced behind the gut and the dorsal tubercle placed at a considerable distance from the nerve ganglion. In addition, as far as we know them, both the eggs and the larvæ of these three species seem very similar. These deep-rooted resemblances would 
appear to warrant the formation of a genus (Gen. Phallusia) were it desirable that a separate genus be formed, and seem far to outweigh the rather trivial differences upon which the existing definition of Gen. Phallusia rests. In all three species the typical form is attached diagonally to the substratum, the apertures are very widely separated, and with the possible exception of $A$. conchilega, the upper limit of whose size requires confirmation, a very large maximum size is attained. The diagonal attachment is necessary if the atrial aperture is to be kept clear of the substratum (Plate 7, Figs. 5-6), whereas, in the remaining species the typical form can well be erect since the apertures are rather closely approximated and anterior (Plate 7, Fig. 4). Only in A. obliqua is there a tendency to oblique attachment, and only $A$. aspersa reaches a size of over $10 \mathrm{~cm}$., with an average size much smaller than that figure. Tubercle and ganglion are closely approximated and the branchial sac does not extend beyond the gut. These species therefore appear to form a natural group from which it is difficult to justify the separation of genus Ascidiella by reason of the lack of real branchial papillæ in the latter and the excessive straying of renal vesicles over the mantle surface. As has been said, the absence of papillæ is only a matter of degree (the appearance of the bars at certain stages of development and from certain angles, has led numerous observers to state that papillæ are to be seen, but on further study all have agreed that real free papillæ, projecting abruptly from the surface of the longitudinal vessels and not being mere thickenings of these vessels, are absent). The extension of the distribution of the renal cells beyond the viscera is simulated in a lesser degree in $A$. prunum. These points of difference are, by comparison, scarcely of generic value when balanced against the more deeply-set features of resemblance with $A$. obliqua, A. virginea, and A. prunum. Also, the implied diminutive in the term Ascidiella is misleading. While there might be considered grounds for the separation of these smaller forms into a genus apart from that which would contain the larger forms, the simpler course is suggested here of bringing together into one genus all the Boreal forms of the Family. To this procedure there appears to be no obstacle arising from the study of developmental characters, at least as far as this study has gone.

\section{KEY TO GENUS ASCIDIA.}

\footnotetext{
(Nerve ganglion adjacent to dorsal tubercle; apertures not more than one-third of the body-length apart; sac not prolonged

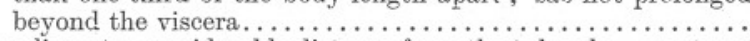
$\{$ Ganglion at a considerable distance from the tubercle ; apertures much more than one-third of the body-length apart; sac prolonged beyond the viscera $\ldots \ldots \ldots \ldots \ldots \ldots \ldots \ldots \ldots \ldots$

2. Typical free papillæ absent from the sac $\ldots \ldots \ldots \ldots \ldots \ldots \ldots$

2. $\left\{\begin{array}{l}\text { Typical free papillæ absent from the sac } \ldots \ldots \ldots \ldots \ldots \ldots \ldots \ldots \ldots \ldots \\ \text { Typical free papillæ present in the sac } \ldots \ldots \ldots \ldots \ldots \ldots\end{array}\right.$ 


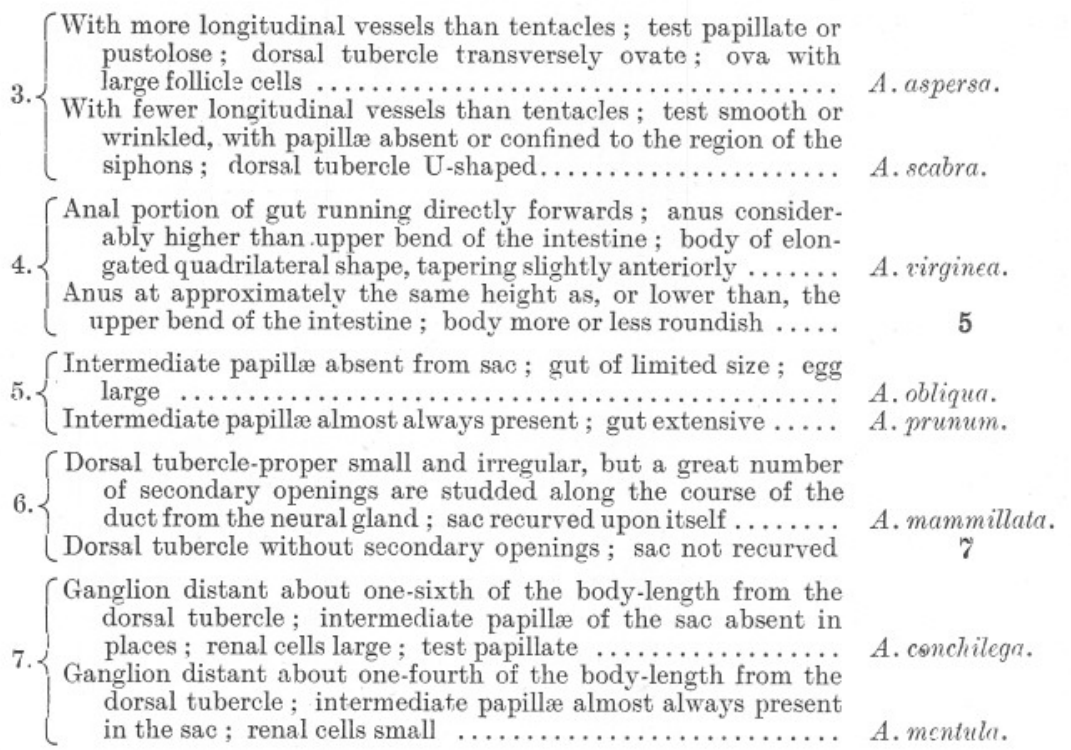

\section{Synonymy.}

(With chief reference to recent British Works).

Ascidia aspersa (Müll. 1776).

$=A$. aspersa + A. truncata $($ Herdman, 1881).

$=A$. aculeata $($ part $)+A$. canina (non. Müll. $)+A$. Normani + do. (var. resplendens $)+A$. affinis $+A$. pustulosa $+A$. scabra (var, echinata) (Alder \& Hancock, 1905).

This species was described by Risso (18) as Phallusia cristata and later by others - including Roule (20)—as Ascidiella cristata. If, as Alder and Hancock thought probable, Müller's A. aspersa was a young stage of A. scabra, the specific name should probably be $A$. cristata. However, the present name has been much used, is expressive, and will probably be allowed to stand.

\section{Ascidia scabra (Müll. 1776).}

$=A$. virginea + A. scabra + A. triangularis (Herdman, 1881).

$=A . \quad$ sordida $+A . \quad$ morei $+A . \quad$ scabra + do. $\quad($ vars. $\quad$ albida + lavis $)+$ A. elliptica + A. pellucida + ? A. orbicularis + ? A. vitrea (Alder \& Hancock, 1905).

=Ascidiella scabra (Roule, 1884). 
Ascidia mentula (Müll. 1776).

$=A$. lata $+A$. fusiformis (Herdman, 1881).

$=A$. mentula $+A$. robusta $+A$. rubicunda $+A$. rubrotincta $+A$. crass $a$ $+A$. mollis + do. (var. carnosa) $+A$. plana + A. Alderi + A. rudis (Alder \& Hancock, 1905).

Ascidia conchilega (Müll. 1776).

$=A$. depressa $+A$. plebeia + A. exigua (Herdman, 1881).

$=A$. depress $a+A$. Roulei $($ part $)+$ do. $($ var. petricola $)+A$. Herdmanni (Garstang, 1891).

$=A$. producta + ? A. inornata $+A$. depressa $+A$. elongata $+A$. aculeata (part) + A. amœna + A. plebeia (Alder \& Hancock, 1905).

Ascidia PRunum (Kupff., 1875).

$=$ A. callosa $($ Stimpson, 1854).

$=$ Phallusia prunum (Kupfi., 1875).

$=A$. glacialis $+A$. prunum (part) + A. complanata (Herdman, 1891).

Ascidia mammillata (Cuv., 1815).

$=$ A. mammillata (Cuv., 1815).

$=$ Do. (Alder \& Hancock, 1905).

Ascidia obliqua (Ald. 1863).

$=A$. obliqua + A. falcigera + A. mollis (Herdman, 1891).

$=A$. obliqua (Alder \& Hancock, 1905).

Ascidia virginea (Müll. 1776).

$=$ A. patoni $($ Herdman, 1881).

$=A$. venosa (Alder \& Hancock, 1905).

\section{SUMMARY.}

1. A detailed investigation is made into the identity of the forms recently grouped under Genus Ascidiella. Two species only have been found to be capable of being differentiated, and these have been re-included under Genus Ascidia.

2. The relative specific importance of certain developmental and body characters is discussed.

3. A new Key to the Boreal species of Family Ascidiida is suggested. NEW SERIES.-VOL. XVIr. No. 1. SEPTEMBER, 1930. 
We are indebted to Mr. E. Ford, of the Marine Laboratory at Plymouth, for sending part of the living material utilised in this investigation. The thanks of one of us (S.T.L.) are due to the Fishery Board for Scotland for permission to work in their Laboratory at Aberdeen, and to the Trustees of the Carnegie Fund for Scottish Universities, from whom she has been in receipt of a Research Scholarship.

\section{REFERENCES.}

1. Alder, J., 1863. Observations on the British Tunicata with descriptions of several new species. Ann. Nat. Hist., ser. 3, XI, pp. 153-173.

2. Alder, J., and Hancock, A., 1905. The British Tunicata. Vol. 1. Ray Society, London.

3. Berrill, N. J., 1928. The identification and validity of certain species of Ascidians. J. Mar. Biol. Assoc., Plymouth (N.S.), XV, pp. 159-175.

4. Cuvier, G., 1815. Mémoire sur les Ascidies et sur leur Anatomie. Mém. Mus. Hist. Nat., II, pp. 10-39.

5. Garstang, W., 1891. On some Ascidians from the Isle of Wight, a study of variation and nomenclature. J. Mar. Biol. Assoc., Plymouth, (N.S.), II, pp. 119-140.

6. Hartmeyer, R., 1915. Alder and Hancock's Britische Tunicaten. Eine Revision. Mitt. Mus. Berlin, VII, 3, pp. 303-344.

7. Hartmeyer, R., 1923. The Danish Ingolf Expedition, Vol. II, 6, Ascidiacea. Copenhagen.

8. Herdman, W. A., 1881. Notes on British Tunicata, with descriptions of new species. I. Ascidiidæ. J. Linn. Soc., London, Zool., XV, pp. 274-290.

9. Herdman, W. A., 1883. Report on the Tunicata collected during the cruise of H.M.S. Triton in the summer of 1882. Trans. Roy. Soc. Edinburgh, XXXII, 1, p. 96.

10. Herdman, W. A., 1889. Second Report upon the Tunicata of the L.M.B.C. District. Proc. Liv. Biol. Soc., III.

11. Herdman, W. A., 1891. A revised classification of the Tunicata. J. Linn. Soc., London, Zool., XXIII, pp. 558-562.

12. Herdman, W. A., 1893. Notes on British Tunicata, Pt. II. J. Linn. Soc., London, Zool., XXIV, pp. 431-454. 
13. Kupffer, C., 1870. Die Stammverwandtschaft zw. Ascidien u. Wirbelthieren. Areh. mikr. Anat., VI, 2, pp. 115-172.

14. Kupffer, C., 1875. Tunicata, in Jahresb. Comm. deutsch. Meere in Kiel, 1872-3, II, p. 211.

15. Linde, A. Ârnbâch-Christie, 1927. Northern and Arctic Invert., IX, Tunicata, 3, Molgulidæ and Pyuridæ. Kungl. Svensk. Vet. Handl., Ser. 3, IV, No. 9.

16. Lohmann, H., 1910. Die Ascidien larven des Nordischen Planktons.

17. Müller, O. F., 1776. Zool. Dan. prodromus.

18. Risso, A., 1826. Phallusia cristata, in Hist. Eur. mérid., IV, p. 276.

19. Stimpson, W., 1854. Synopsis of the Marine Invert. of Grand Manan. Smithson-Contrib. Knowl., VI, p. 19.

20. Roüle, L., 1884. Recherches sur les Ascidies simples des côtes de Provence. Phallusiadées. Ann, Mus. Marseille, II, Zool., I. 


\section{PLATE 1.}

Eggs of Fam. Ascidiida. ( $\times 110$. Zeiss Camera Lucida.)

Fig. 1.-Ascidia mentula.

FIg. 2.-Ascidia virginea.

Frg. 3.-Ascidia conchilega.

FIg. 4.-Ascidia mammillata.

FIG. 5.-Ascidia scabra (2 hours after emission).

FIG. 6.-Ascidia aspersa (2 hours after emission).

FIG. 7.-Ascidia prunum (calculated size of chorion).

Frc. 9.-Ascidia obliqua (calculated size of chorion).

Frg. 8.-Corella parallelogramma. (Fam. Rhodosomatidae.

Fig. 10.-Egg in oviduct of A. scabra.

FIc. 11.-Egg in oviduct of $A$. aspersa. 
PLATE 1
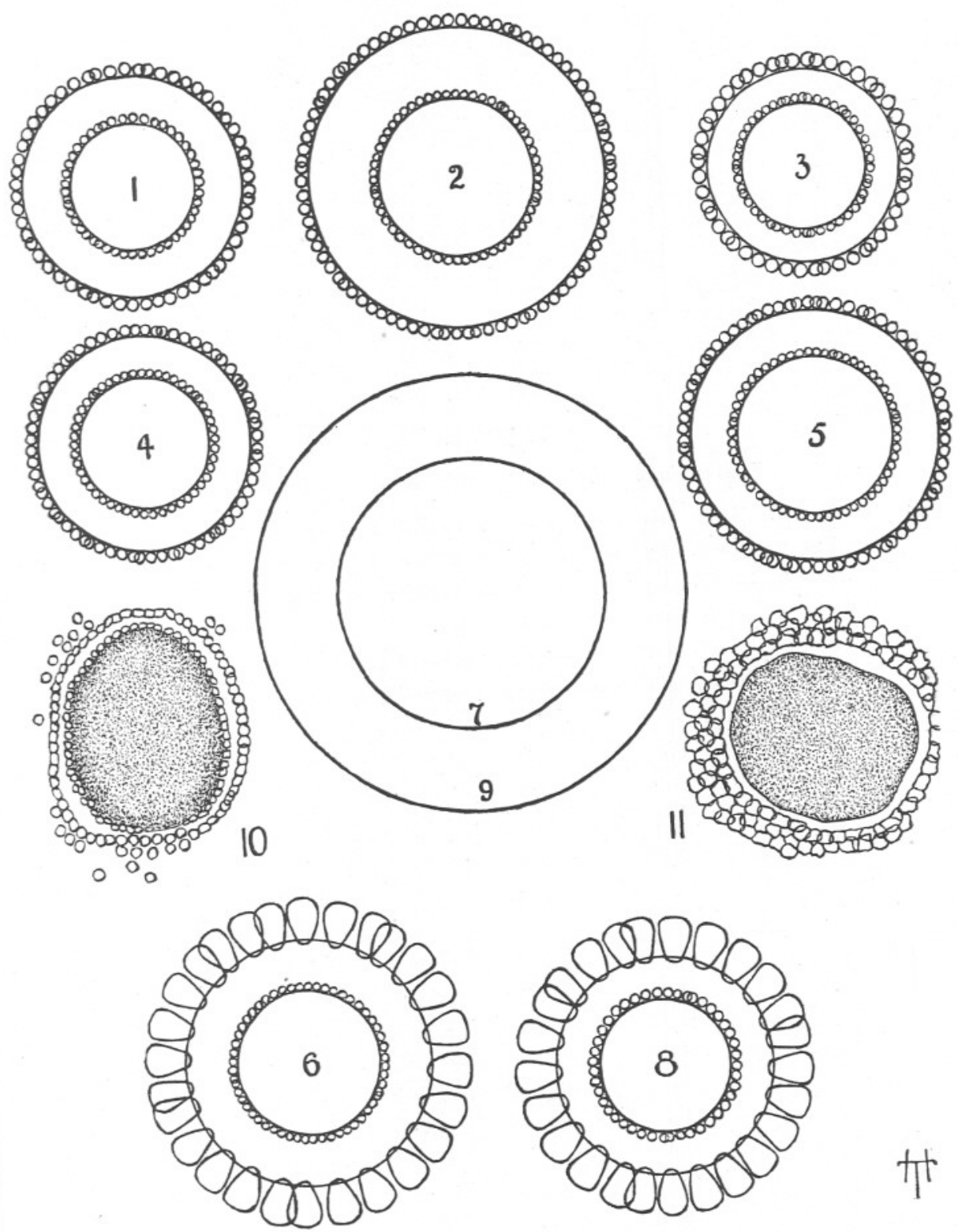


\section{PLATE 2.}

Eggs of Fam. Ascidiida. ( $\times 110$. Zeiss Cam. Lucida.)

Fig. 1.-Ascidia asperse (Plymouth). 10 mins. after emission.

Fig. 2.-Ascidia aspersa (Plymouth). 2 hours after emission.

FIG. 3.-Ascidia aspersa (Islay). One day after emission.

Fig. 4.-Ascidia scabra (Plymouth). May.

FIg. 5.-Ascidia scabra, escaping larva (Aberdeenshire coast). August.

FIg. 6.-Ascidia mammillata, escaping larva (Plymouth). 

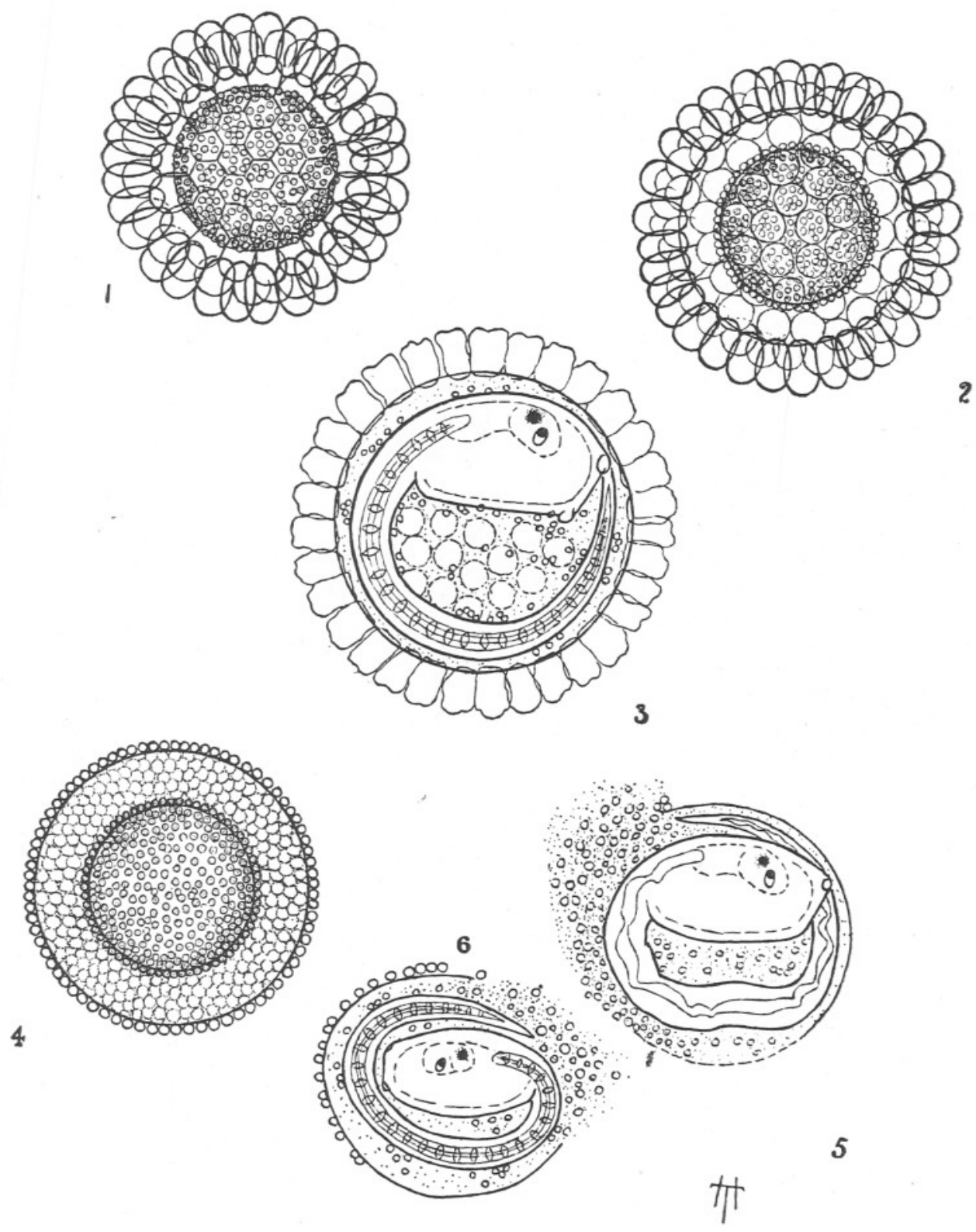
S. T. LINDSAY AND H. THOMPSON.

\section{PLATE 3.}

Larvæ of Fam. Ascidiida. $(\times 104 . \quad$ Zeiss Cam. Lucida. $)$

FIg. 1.-Ascidia aspersa (Plymouth). Left side, oblique view.

Fig. 2.-Ascidia aspersa (Islay). Cf. Fig. 3, Plate 2.

FIg. 3.-Ascidia scabra (Plymouth, Aberdeen, Loch Eriboll, etc.). Cf. Fig. 5, Plate 2.

FIg. 3a.-Ascidia scabra (North Sea), an example of smaller late season (October) larvæ (cf. Fig. 3).

FIG. 4.-Ascidia mentula.

FIG. 5.-Ascidia mammillata. 
PLATE 3.

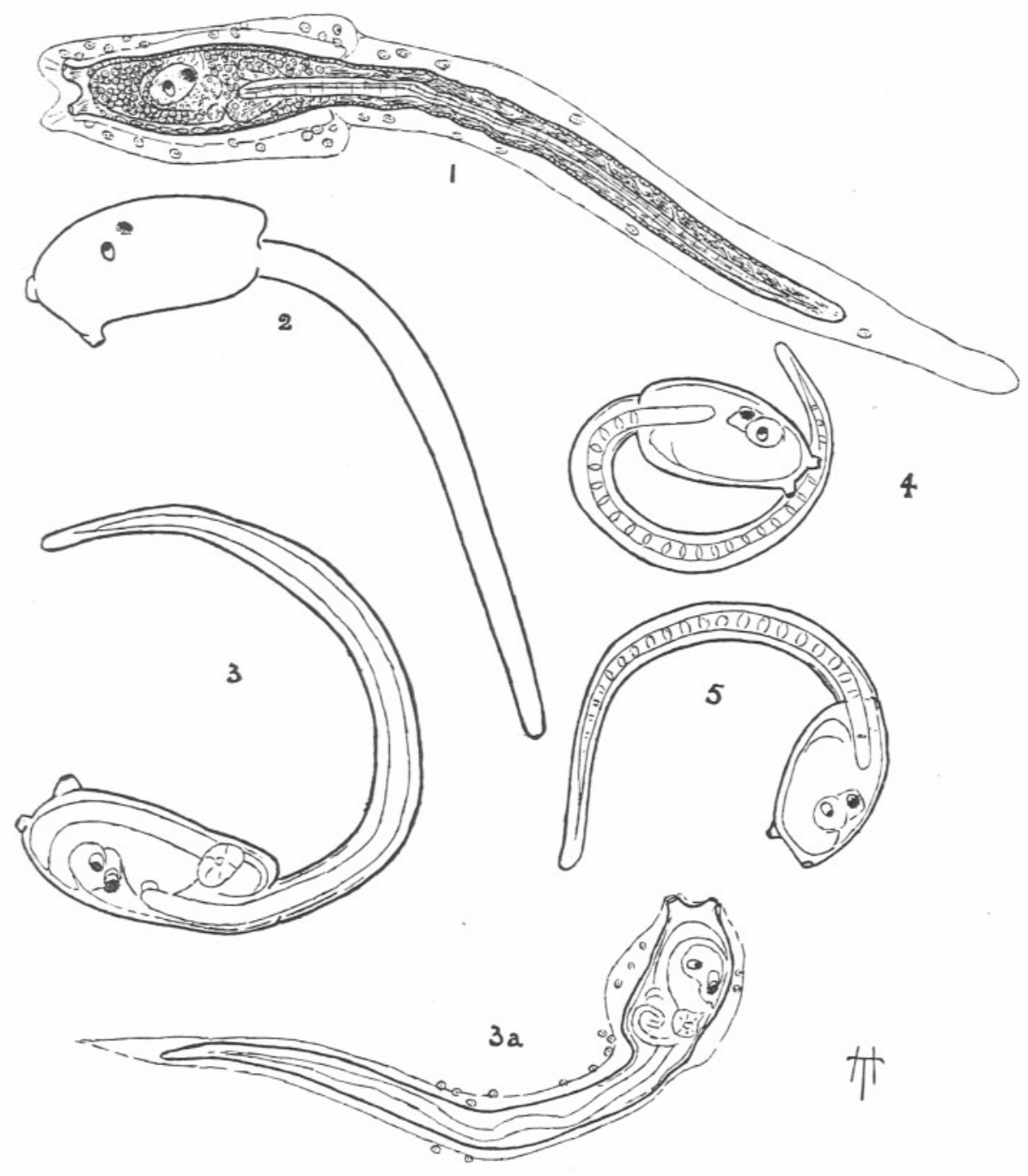


PLATE 4.

Types of Fixation and Habit in Fam. Ascidiidar. (Seven-eighths natural size.)

FIgs. 1-4.-Ascidia scabra.

Frg. 1.-Attached by side (Luce Bay).

Fig. 2.-A specimen from Firth of Clyde. The apertures are unusually wide apart.

FIg. 3.-Attached by base. A typically transparent specimen from Moray Firth.

FIG. 4.-Attached by base. Large Dogger Bank form.

Frgs. 5-6.-Ascidia virginea.

Fic. 5.-Attached by base (normal method of fixation).

FIG. 6.-Attached by side (abnormal method of fixation). 
PLATE 4.
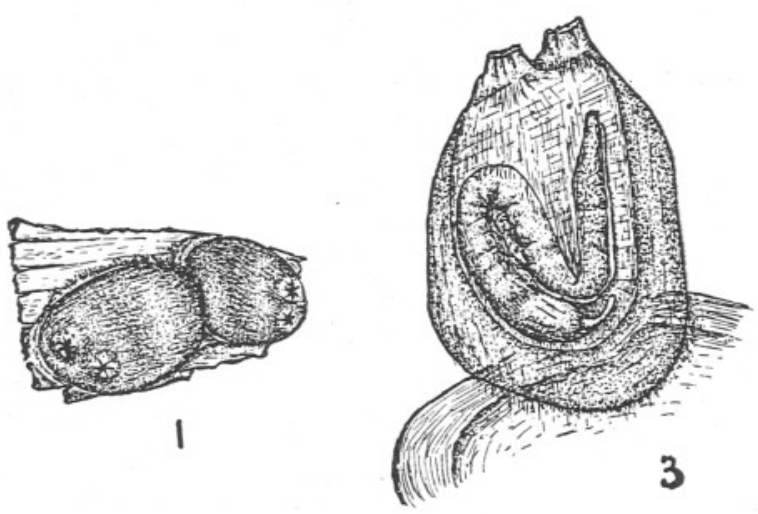

2
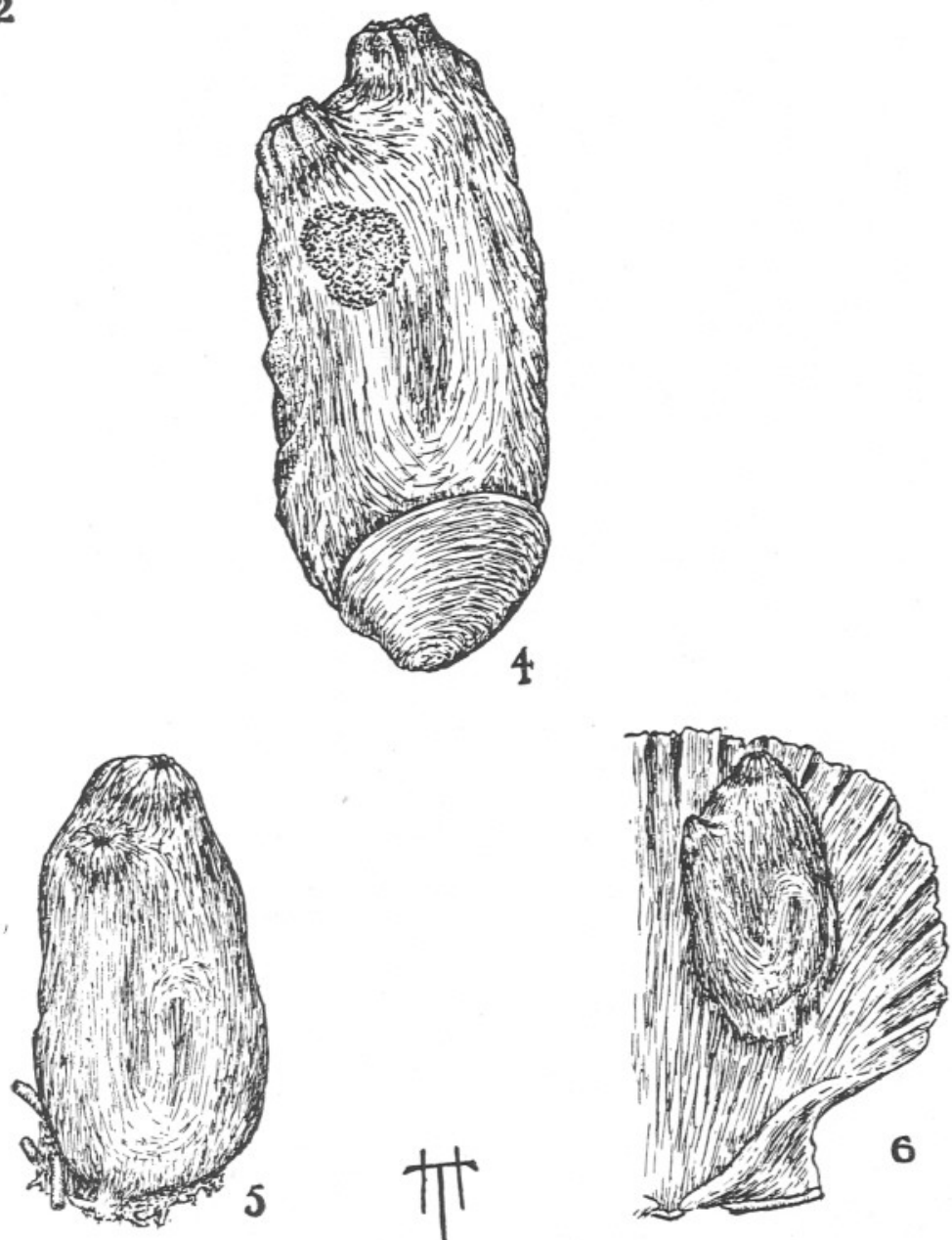
PLATE 5.

Types of fixation (continued).

Fig. 1.-Ascidia aspersa. Basal attachment (Plymouth).

FIG. 2.-Ascidia aspersa. Attached by side (Loch Indail, Islay). (Both figures natural size.) 
PLATE 5.
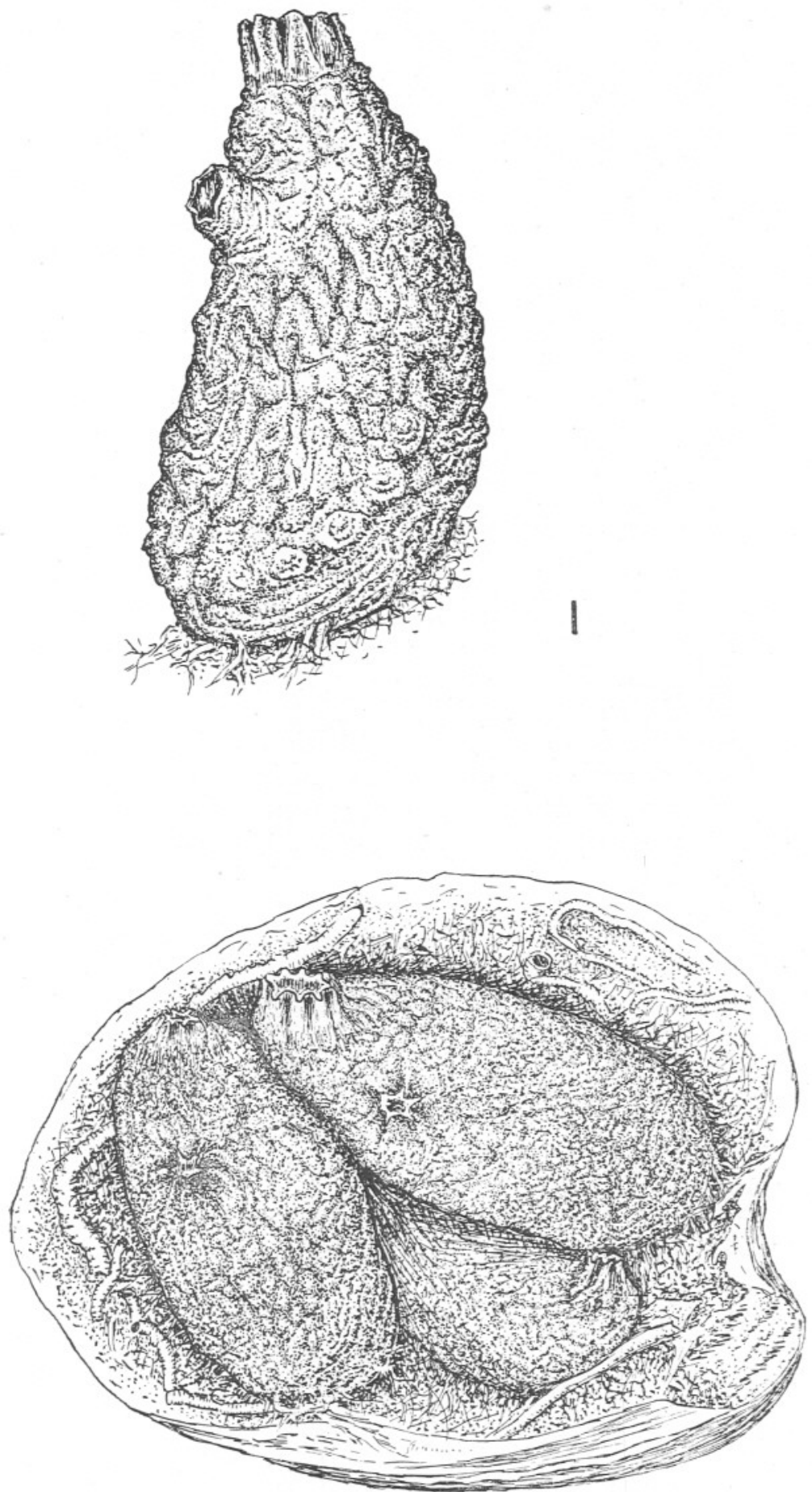


\section{PLATE 6.}

Dorsal Tubercles and Tentacles of Ascidia aspersa and Ascidia scabra. (Zeiss Cam. Lucida.)

Figs. 1-5.-Variation in form of Dorsal Tubercle in A. aspersa. Figs. 2 and 4 are the normal form; Fig. 1 ( $\times 3 \frac{1}{2}$ times ordinary scale) from a very small Plymouth specimen, $6 \mathrm{~mm}$. in size; Figs. 2 and 3 are from Plymouth, and Figs. 4 and 5 from Loch Fyne specimens.

Figs. 6-26.-Variation in form of Dorsal Tubercle in A. scabra. Figs. 6-16 from a random selection of specimens from the northern Moray Firth ; Figs. 15 and $16\left(\times 3 \frac{1}{2}\right.$ times ordinary scale) from very small specimens (9 and $12 \mathrm{~mm}$.) ; Fig. 17 from Loch Fyne ;

Figs. 18-20 from Luce Bay ; Fig. 21 from Dogger Bank ; Figs. 22-26 from Plymouth.

FIG. 27.-A group of tentacles from A. aspersa (Plymouth), of size $40 \mathrm{~mm}$. ( $\times 18)$.

FIG. 28.-A group of tentacles from A. scabra (Dogger Bank), of size $40 \mathrm{~mm} .(\times 18)$. 
PLATE 6 .

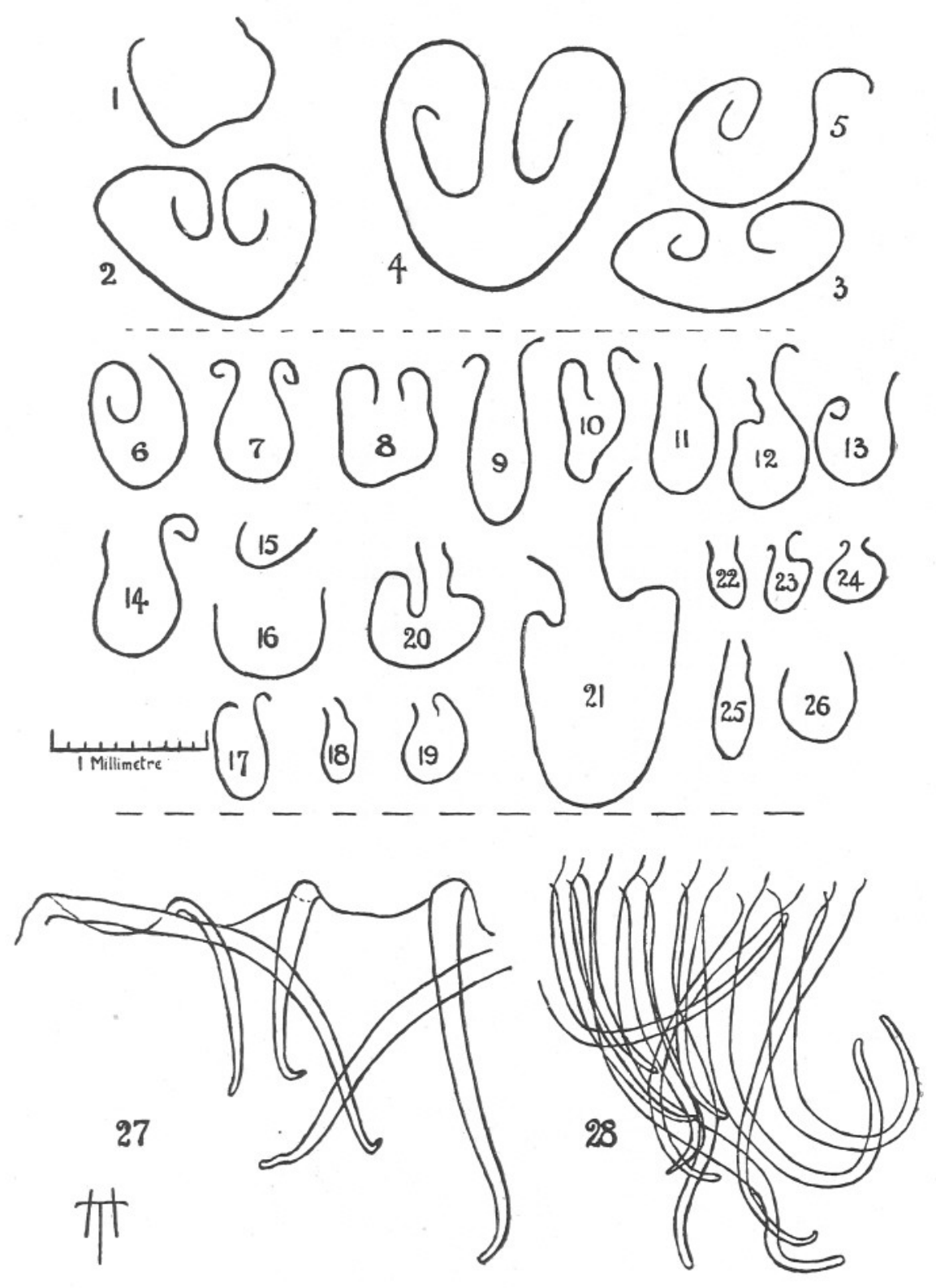




\section{PLATE 7.}

Figs. 1-3.--Portions of Branchial Sac.

Frg. 1.-Ascidia aspersa. Size $30 \mathrm{~mm}$. (from Loch Indail, Islay), pseudo-papillæ on present $(\times 60$, Zeiss C.L.).

Frg. 2.-Ascidia aspersa. Size $8 \mathrm{~mm}$. (from L. Indail).

$a .=$ Knob-like vascular processes, simulating papillæ.

b. =A similar process linked up with its neighbour by a longitudinal $\mathrm{b}$. $(\times 110$, Zeiss C.L.).

Fra. 3.-Ascidia mentula. Showing typical free papillæ $(\times 60$, Zeiss C.L.).

Figs. 4-6.-Illustrating mode of attachment.

Fra. 4.-Ascidia virginea. Basal attachment is normal; apertures are well clear substratum.

Fra. 5.-Ascidia mentula. Showing how basal attachment (none occurs in this specie would bring position of atrial aperture near to substratum.

Fig. 6.-A. mentula. Normal oblique attachment by side, atrial aperture free substratum. 
PLATE 7 .
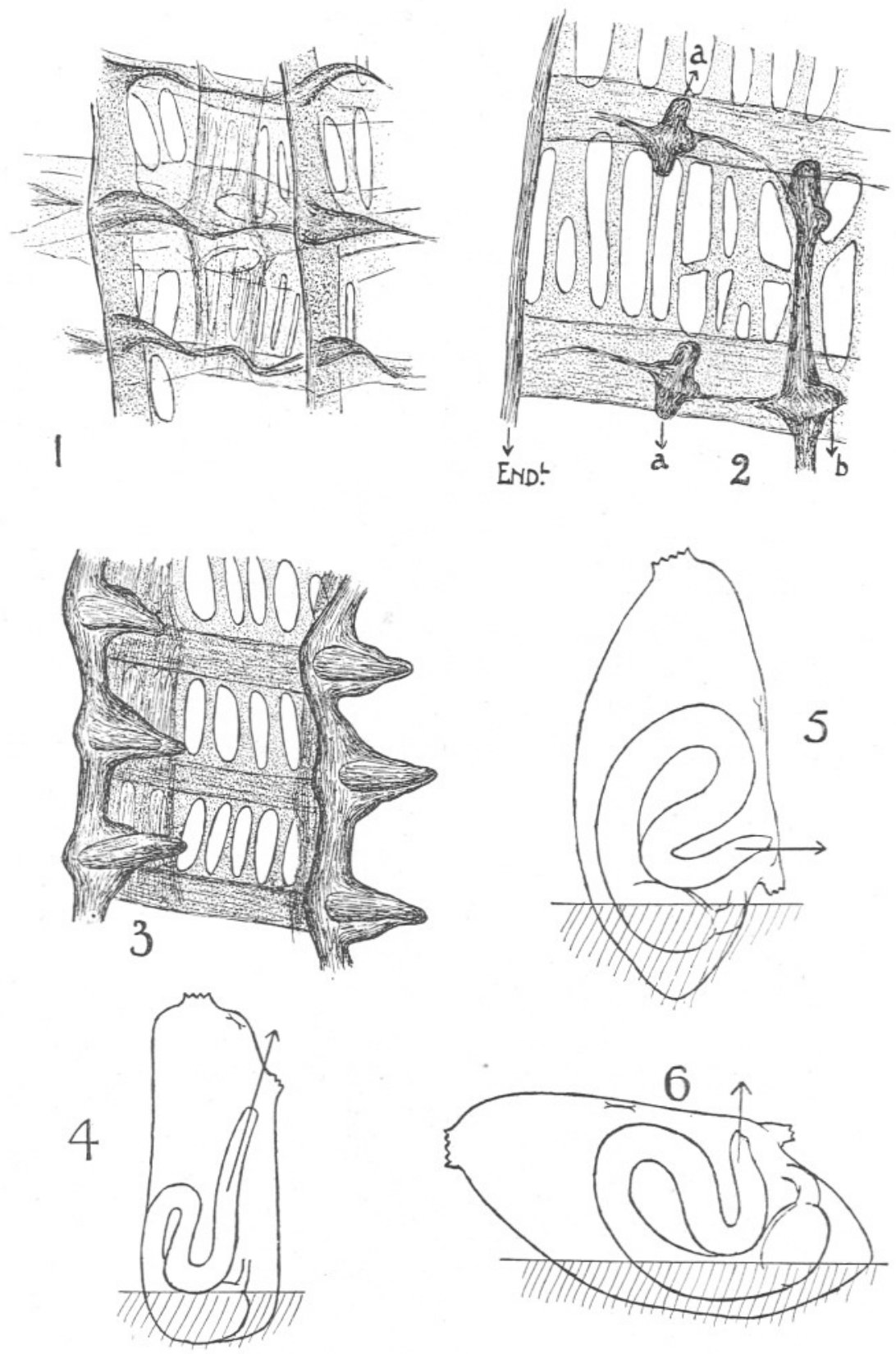

NEW SERIES.-VOL. XVII. No. 1. SEPTEMBER, 1930. 
PLATE 8.

A specimen of $A$. scabra showing double atrial siphon (Test removed). Fig. 1.-From right side, showing musculature of mantle.

FIG. 2.-From left side, showing extension of renal cells beyond the viscera. Both Figs. about three times natural size.

(Photographs by Mr. John McKenzie, of the Staff of the Fishery Board for Scotland.) 
PLATE 8.
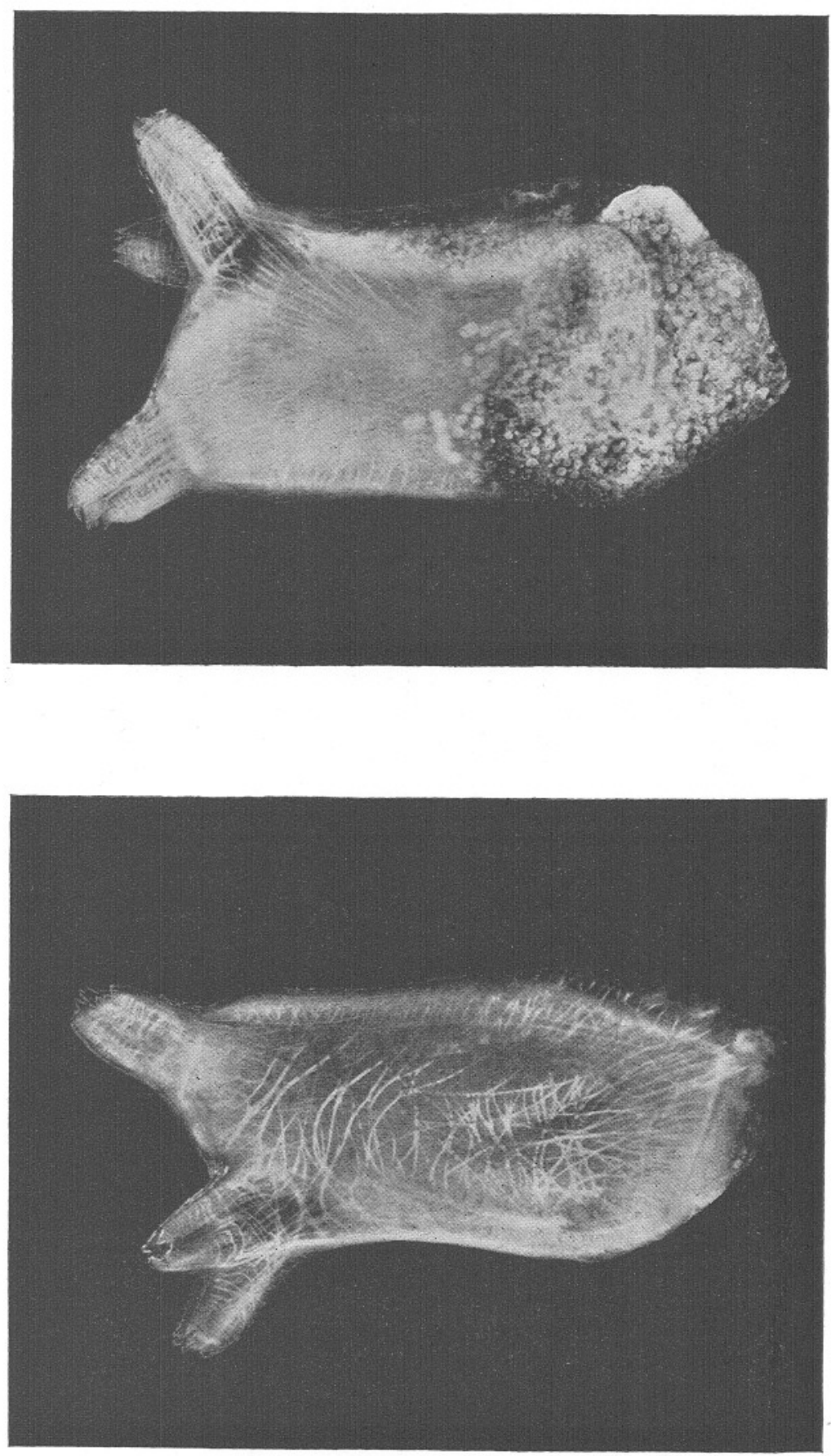
